\title{
Fiscal policies and the prices of labor: a comparison of the U.K. and U.S.
}

Casey B. Mulligan

Correspondence: c-mulligan@ uchicago.edu

University of Chicago, Chicago, USA

\begin{abstract}
This paper measures the 2007-13 evolution of employment tax rates in the U.K. and the U.S. The U.S. changes are greater, in the direction of taxing a greater fraction of the value created by employment, and primarily achieved with new implicit tax rates. Even though both countries implemented a temporary "fiscal stimulus," their tax rate dynamics were different: the U.S. stimulus increased rates, whereas the U.K. stimulus reduced them. The U.K. later increased the tax on employment during its "austerity" period. Tax rate measurements are a first ingredient for cross-country comparisons of labor markets during and after the financial crisis.
\end{abstract}

JEL Codes: E24, H31, 138, J22

Keywords: Marginal tax rates; Employment; International comparisons

\section{Introduction}

Many countries of the world experienced an unusually deep and long recession after 2007. Over the same time frame, several facets of fiscal policy were changed, especially policies related to taxation and safety net programs. The purpose of this paper is to compare changes in fiscal policy parameters as they affected the incentives of middleclass Americans and British to be employed. The U.K. had a "stimulus programme" followed by an "austerity programme." The U.S. federal government also passed what it called a "stimulus package," followed by a major health reform.

Policy labels acquired during legislative processes are not necessarily indicative of economic fundamentals. This paper comparably quantifies fiscal policy in terms of one of the fundamentals: the wedge between the supply price of labor and the demand price of labor. It finds that the two countries have been different in terms of the evolution of employment taxation, on average and across demographic groups. The American stimulus reduced average incentives to be employed by increasing cash and health benefits for the unemployed and for families with low incomes, whereas the British stimulus did the opposite by temporarily reducing its value-added tax rate and permanently reducing its basic income tax rate. The British austerity program pushed incentives in the opposite direction as its stimulus by permanently increasing its payroll and value-added tax rates.

The evolution of employment has also been different in the two countries. Figure 1 displays an index of each country's employment rates for prime-aged people. ${ }^{1}$ Employment fell sharply in both countries during the crisis, although less so in the U.K. The U.K. employment recovery began earlier, and by the end of 2014 the U.K. 


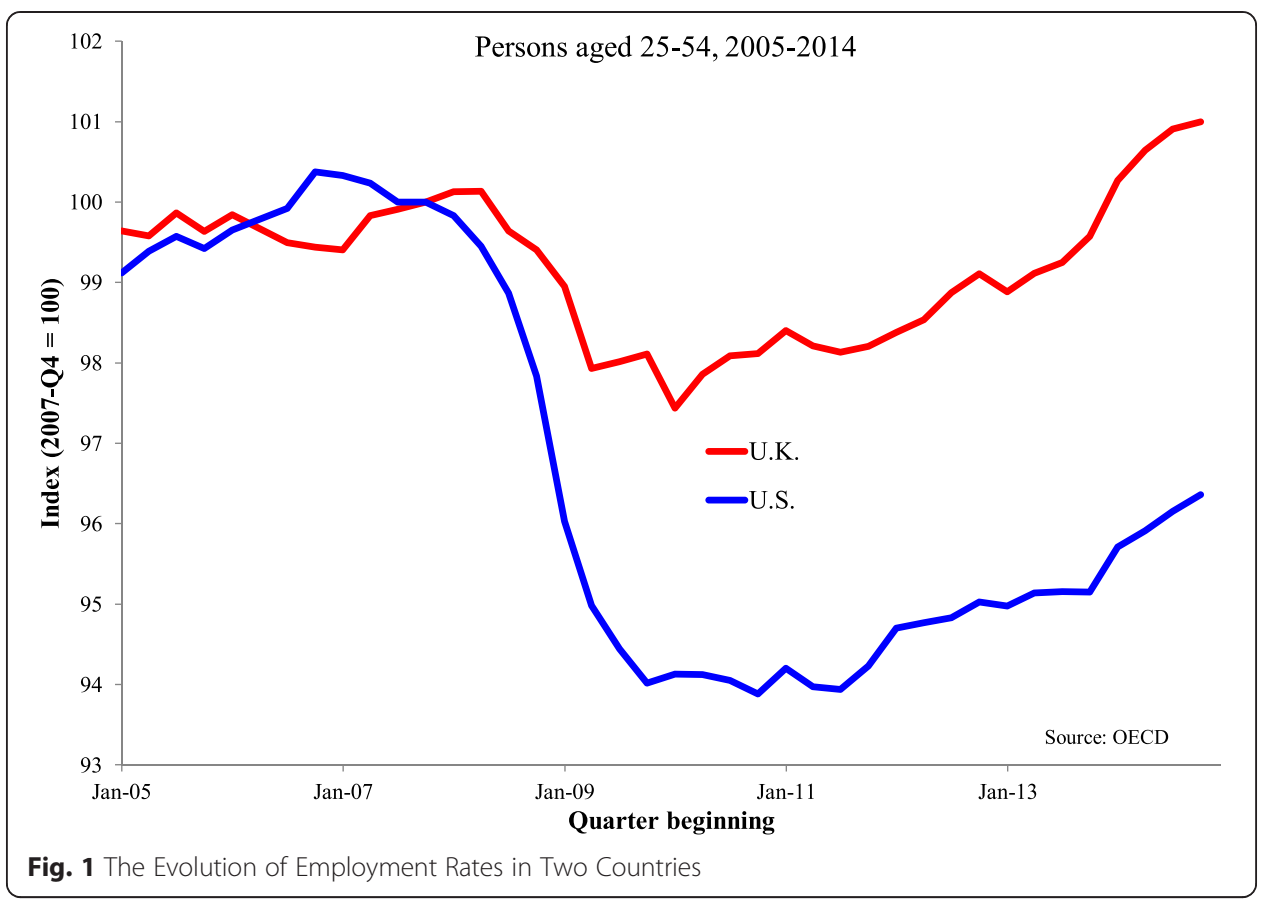

employment rate had exceeded pre-crisis levels. Because taxes are one (among many) of the determinants of labor market performance, comparable tax measures are necessary for carefully investigating and comparing labor market outcomes. This paper provides tax measures, and shows how changes in tax rates are linked to specific legislation.

Taxes potentially affect work decisions in a variety of dimensions, for example: the number of weeks worked per year, the number of hours worked per week, whether to work at all during a year, and the amount of effort to put into work. Due to the prominence of the business cycle during this period and the sheer size of gross monthly employment flows, this paper focuses on the weeks-per-year margin, holding constant weekly hours and the probability of not working at all during a calendar year. In the $21^{\text {st }}$ century U.K., for example, the single largest quarterly employment decline for the non-elderly population has so far been 0.3 million, as compared to at least 2.6 million non-elderly people who join or separate from an employer during the average quarter. ${ }^{2}$ Adding just one week out of work before joining, or after separating, would therefore create a remarkable net reduction in the number employed at a point in time. Also, the large majority of unemployment spells last less than 12 months, and some of those lasting 12 months do not blanket an entire tax year. ${ }^{3}$

I follow the usual steps of public finance analysis and first look at the tax wedge the gap between supply and demand prices created by a tax or subsidy. The next step, left for future research, is to draw conclusions about the wedge's behavioral effects and ultimate incidence. Thus, with one exception noted below, the estimates in this paper do not require any assumption about the relative incidence of labor taxes on employers and employees.

Section 1 discusses the United Kingdom, demonstrating how many of the tax changes were ultimately offsetting in terms of the employment incentives they created. The primary exception relates to the subpopulation receiving child tax credits, because the phaseout (sometimes referred to as "taper") rate of those credits increased with little 
change in the range of incomes over which the phaseout applies. Section 2 shows results for the United States, where employment disincentives have increased over time, especially (but not exclusively) among unmarried workers. Section 3 shows the evolution of the employer cost and employee benefit from work - the gap between the two is the employment tax wedge - by country for workers in the middle of the wage distribution.

\section{Fiscal policy and the reward to work: the United Kingdom}

\subsection{A worker's tax year budget constraint}

My model of the U.K. worker features a consumption tax, payroll taxes (by both employer and employee; hereafter, NICs or "National Insurance Contributions," as they are called in the U.K.), personal income taxes, benefits based on personal income (such as working tax credits, child tax credits, and the child benefit), and benefits for the unemployed (including, but not necessarily limited to, jobless and housing allowances). ${ }^{4}$ The weekly employer cost of worker $i, y_{i}$, is the sum of weekly earnings $w_{i}$ and employer payroll taxes $\left(w_{i}-S T\right) \tau_{f}$ :

$$
y_{i}=w_{i}+\left(w_{i}-S T\right) \tau_{f},
$$

where $\tau_{f}$ denotes the marginal employer NICs rate and $S T<y$ denotes the earnings threshold for weekly employer NICs.

The personal income tax and personal-income-related benefits are based on tax-year income (the tax year begins in April), but the NICs and unemployment benefits are weekly. The link between consumption $c_{i}$ and weekly earnings $w_{i}$ therefore depends on the number of weeks worked $n_{i} \in[0,52]^{5}$ :

$$
c_{i}=\left(52-n_{i}\right) U B_{i}+w_{i} n_{i}-\left(w_{i}-P T\right) n_{i} \tau_{e}-P I T\left(\left(52-n_{i}\right) U B_{i}+w_{i} n_{i}\right)-\tau_{c} c_{i},
$$

where $\tau_{e}$ is the marginal employee NICs rate, $U B$ denotes the weekly unemployment benefit, $^{6}$ and $\operatorname{PIT}(\cdot)$ denotes the combined schedules for personal income taxes, working tax credits, child tax credits, and the child benefit. ${ }^{7} P T<y$ denotes the earnings threshold for weekly employee NICs. PT is known as the "primary threshold," as distinct from the "secondary threshold" ST applicable to employers. ${ }^{8}$ Equation (2)'s last term refers to indirect or consumption taxes (primarily VAT, but also important contributions from excise taxes: see Appendix I), which are levied as a fixed fraction $\tau_{c}$ of consumption before tax. Combining (1) and (2), we have consumption as a function of weekly employer cost and weeks worked:

$$
\begin{aligned}
\left(1+\tau_{c}\right) c_{i}= & 52 U B_{i}+\left[\frac{1-\tau_{e}}{1+\tau_{f}} y_{i}+\frac{\tau_{e} P T+\tau_{f} S T}{1+\tau_{f}}-U B_{i}\right] n_{i} \\
& -P I T\left(52 U B_{i}+\left[\frac{y_{i}}{1+\tau_{f}}+\frac{\tau_{f}}{1+\tau_{f}} S T-U B_{i}\right] n_{i}\right)
\end{aligned}
$$

The consumption tax rate is assumed to be constant across workers, but $U B$ varies across workers due to family composition and housing expenses.

As indicated in equations (1) and (2), a fixed amount of earnings - the "primary" and "secondary" thresholds (PT and ST, respectively) - can be earned without any NICs owed by employee or employer. ${ }^{9}$ The NICs system is therefore equivalent to a truly flat-rate payroll tax (specifically, without any PT or ST) plus a refund of a fixed amount 
to each employee and employer equal to the flat-rate tax that accrued on the first PT (or ST) of earnings. Equation (3) separates the "flat-rate" component from the PT-ST-refund component, with the former represented by the $y_{i}$ terms and the latter by the ratio with $P T$ and $S T$ in the numerator.

The U.K. personal income tax is a function of personal income above the "personal allowance." There are multiple tax brackets, some of which are created by the phaseout of the personal allowance. All of these are represented by my PIT notation.

Unlike U.S. Social Security contributions, the NICs thresholds and rates are administered each pay period (e.g., weekly) without regard for earnings accumulated so far during the tax year. As a result, equation (3)'s PT and ST terms enter the budget constraint in the same way that the $U B$ term does, except with the opposite sign. In effect, the PT-ST-refund component of my two-part representation of the NICs is, by itself, a weekly employment subsidy.

An additional week of employment creates value $y_{i}$, some of which goes to the employee (to finance additional consumption) and the rest of which goes to the public treasury in the forms of additional taxes, credits not paid, and other benefits not paid. The employment tax wedge $q_{i}$ is the public-treasury portion of this value, expressed as a share of weekly employer $\operatorname{cost}^{10}$ :

$$
q_{i} \equiv \frac{y_{i}-\frac{\partial c_{i}}{\partial n_{i}}}{y_{i}}=\frac{1}{1+\tau_{c}}\left(\tau_{c}+\frac{\tau_{i}+\tau_{e}+\tau_{f}}{1+\tau_{f}}+\left(1-\tau_{i}\right) \frac{U B_{i}}{y_{i}}-\frac{\tau_{e} P T+\left(1-\tau_{i}\right) \tau_{f} S T}{\left(1+\tau_{f}\right) y_{i}}\right),
$$

where $\tau_{i}$ denotes worker $i$ 's PIT bracket. The PIT brackets vary across workers according to the amount they earn for the year, although a majority of workers are in the "basic rate" bracket of 20 or 22 percent (depending on the year) plus, for some of the basic-rate workers, a phaseout of tax credits. ${ }^{11}$

Equation (4) has a consumption-tax term multiplying the $U B, P T$, and $S T$ terms (as well as the others), thereby giving the impression that a consumption tax increase would reduce the contribution of the $U B, P T$, and $S T$ terms to the tax wedge. However, because jobless allowances and the NICs thresholds are automatically indexed to consumer-price inflation, and employer cost $y$ is not, the contribution of these two terms to the wedge is independent of the consumption tax as long as the consumption tax is passed through one-for-one into consumer prices. ${ }^{12}$ To put it another way, the consumption tax rate is expected to increase each ratio $U B / y, P T / y$, and $S T / y$ in the same proportion that it reduces the ratio $1 /\left(1+\tau_{c}\right)$.

\subsection{Legislative changes since 2007: wage income tax brackets}

Each of equation (4)'s statutory parameters changed after 2007. Moreover, real employer costs $y$ were changing relative to the sterling-denominated and inflationadjusted statutory parameters such as the jobless allowance and the PT. As I show below, many of the parameter changes are offsetting - perhaps by design - in terms of their effects on the employment tax wedge $q$. Because of the various offsets, the VAT (value-added tax) and tax credit changes ultimately drive most of the changes in the tax wedge.

Beginning at 17.5 percent, the standard VAT rate was temporarily cut to 15.0 percent for the last month of 2008 and the entire calendar year of $2009 .{ }^{13}$ It was 17.5 percent again in 2010. 
On January 4, 2011, the rate was permanently increased to 20 percent where it is now. The UK VAT increases are especially interesting for the purposes of labor market analysis because a VAT reduces the purchasing power of wages without reducing the purchasing power of jobless benefits because the latter are indexed to the consumer price index (CPI).

The UK made several adjustments to its personal income tax on earnings, which has been a three or four-bracket system (plus implicit brackets for the phaseouts of tax credits and the personal allowance). Effective April 2008, the bottom two non-zero brackets of 10 percent and 22 percent were combined into a single 20 percent bracket, as it is today. Effective April 2010, the personal allowance was phased out beginning at $£ 100,000$, and the upper bracket of 40 percent was split in two brackets: 40 percent and 50 percent. A year later, the income threshold separating the 20 and 40 percent bracket was cut by three percent in nominal terms (seven percent in real terms), thereby creating a group of taxpayers who experienced a twenty percentage point increase in their bracket. The 50 percent bracket rate was cut to 45 percent effective April 2013. ${ }^{14}$

The 2010 income tax changes helped harmonize the PIT with the NICs and thereby produce a more uniform combined marginal tax rate schedule among most full-year workers. Figure 2 shows those combined rates (excluding tax credit phaseouts - more on these below) as summarized on the vertical axis by the first ratio term inside equation (4)'s parentheses. The horizontal axis shows employer cost, which is the sum of the worker's annual earnings and the employer NICs. The black-dotted schedule is from tax year 2007. The schedule dips sharply between about $£ 42,000$ and $£ 49,000$ because those workers had exceeded the upper earnings limit for the NICs but still had low enough income that their PIT bracket had not jumped from 20 to 40 percent. $^{15}$ By 2009 , these two thresholds were, up to rounding error, identical for a full-year worker. ${ }^{16}$ These rounding errors are seen as the thin spikes in the red and blue series. ${ }^{17}$

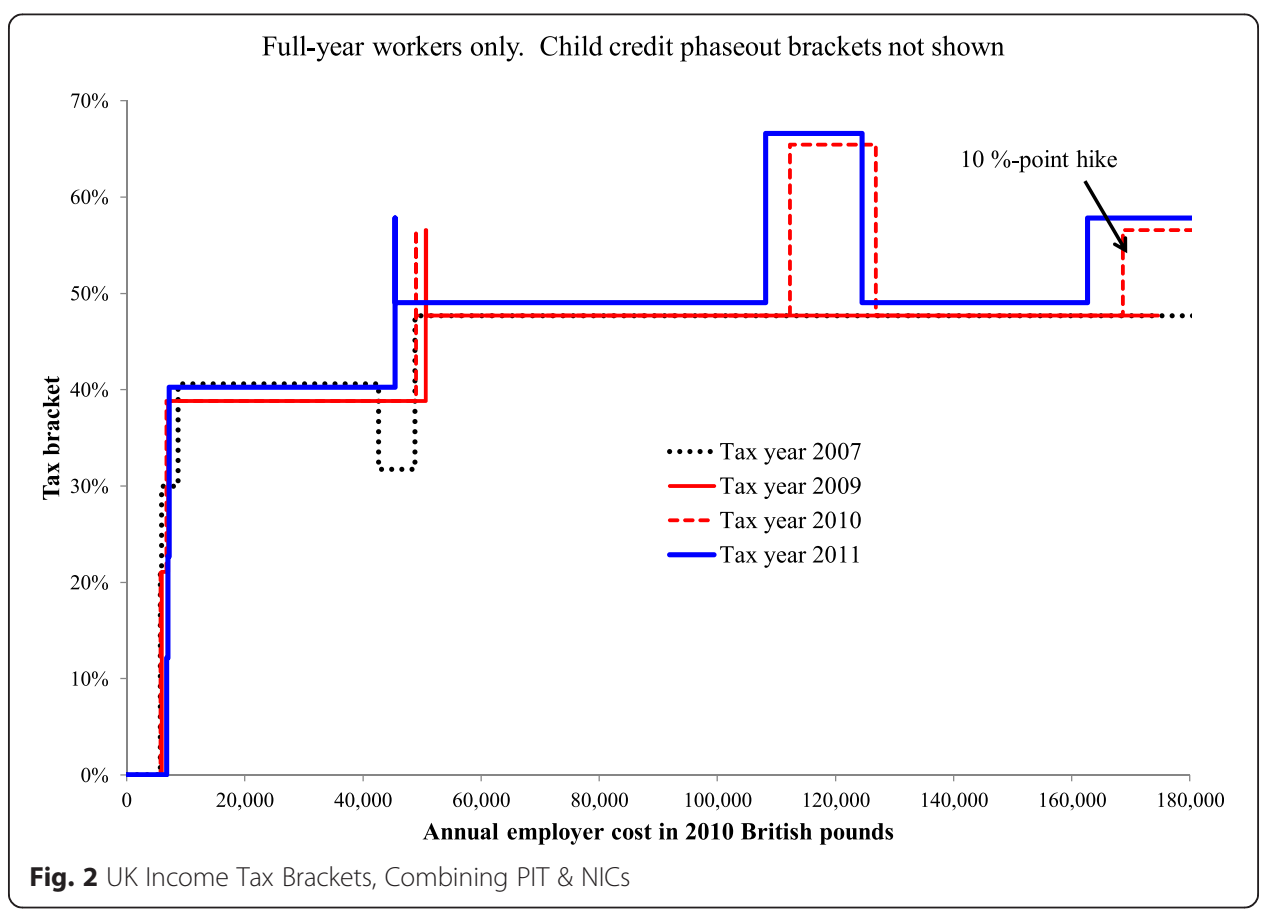


One result of the ongoing threshold changes is that the 2010 and 2011 cuts to the realincome threshold between the 20 and 40-percent PIT brackets only increased overall marginal rates by about 10 percentage points for taxpayers with incomes between the old and new thresholds because much of their 20-point PIT marginal rate increase was offset by being moved into a lesser marginal NICs rate.

Effective April 2011, one percentage point was added to both the employer NICs and the employee NICs (HM Revenue and Customs 2014a). For the workers (they are a majority of taxpayers and have annual employer cost between $£ 7,000$ and $£ 43,000$ ) that would have been in the 22 percent personal income bracket under 2007 law, the additions to the marginal NICs rate almost exactly offset the 2-percentage point PIT cut after 2007. As a result, the solid-blue and black-dotted schedules almost coincide in that range, with the blue 2011 schedule located just 0.4 percentage points below the 2007 schedule.

Among the relatively few high-income taxpayers, the combined contribution of the PIT and NICs changes has been to increase the employment tax wedge. The contribution of these PIT and NICs changes to the overall average employment tax wedge is essentially zero.

In order to highlight the harmonization of the PIT and NICs brackets, Fig. 2 excludes the phaseout of "tax credits." Two main tax credits are paid to households: working tax credits (WTCs) and child tax credits (CTCs). Both credits are a function of annual household income and prorated according to the beneficiary's payment period (weekly or every four weeks). ${ }^{18}$ In 2014, the full credits apply for annual household incomes between $£ 0$ and $£ 6,420$ (HM Treasury 2013). The WTC is phased out between $£ 6,420$ and about $£ 18,000$, depending on household circumstances, and at the same rate as the CTCs. Without beginning to count spousal income or income from job seekers allowances, someone earning the median wage in a full-time full-year job (hereafter "the median") would earn about $£ 23,000$ and therefore not receive any WTC on the weekly employment margin (4) unless he was out of work much of the year and did not have significant income from other sources. ${ }^{19}$ For this reason, this paper gives more attention to the CTCs, which are phased out above annual household income of $£ 18,000$ (or so, depending on circumstances) until about $£ 26,000$ for one child and $£ 33,000$ for two children. ${ }^{20}$

Figure 3 shows the income ranges over which CTCs were phased out, in selected years. Relative to the median wage, the phase-out range widened somewhat between 2007 and 2013. By 2013, a household with 2 children could have an income of up to $£ 32,400$ (at the median wage, an individual's 2013 full-time full-year earnings would be only about $£ 22,000$ ) and still be receiving some CTC. ${ }^{21}$ But the more significant change has been in the increase in the phase-out rate from 37 percent to 41 percent. As I show below, these four percentage points are a large part of the work incentive because already in 2007 workers paying the basic rate and receiving CTC were keeping only 20 percent of their employer's cost at the margin.

In summary, VAT rates, NICs parameters, personal income tax rules, and tax credit rules all changed after 2007. The next step is to use equation (4) to determine the direction and quantitative importance of the changes for incentives to be employed.

\subsection{Changes since 2007: overall employment tax rates}

Employment during a week creates income for the tax year and for this reason alone creates income and payroll tax liabilities - at the rates displayed in the previous section. In addition, 


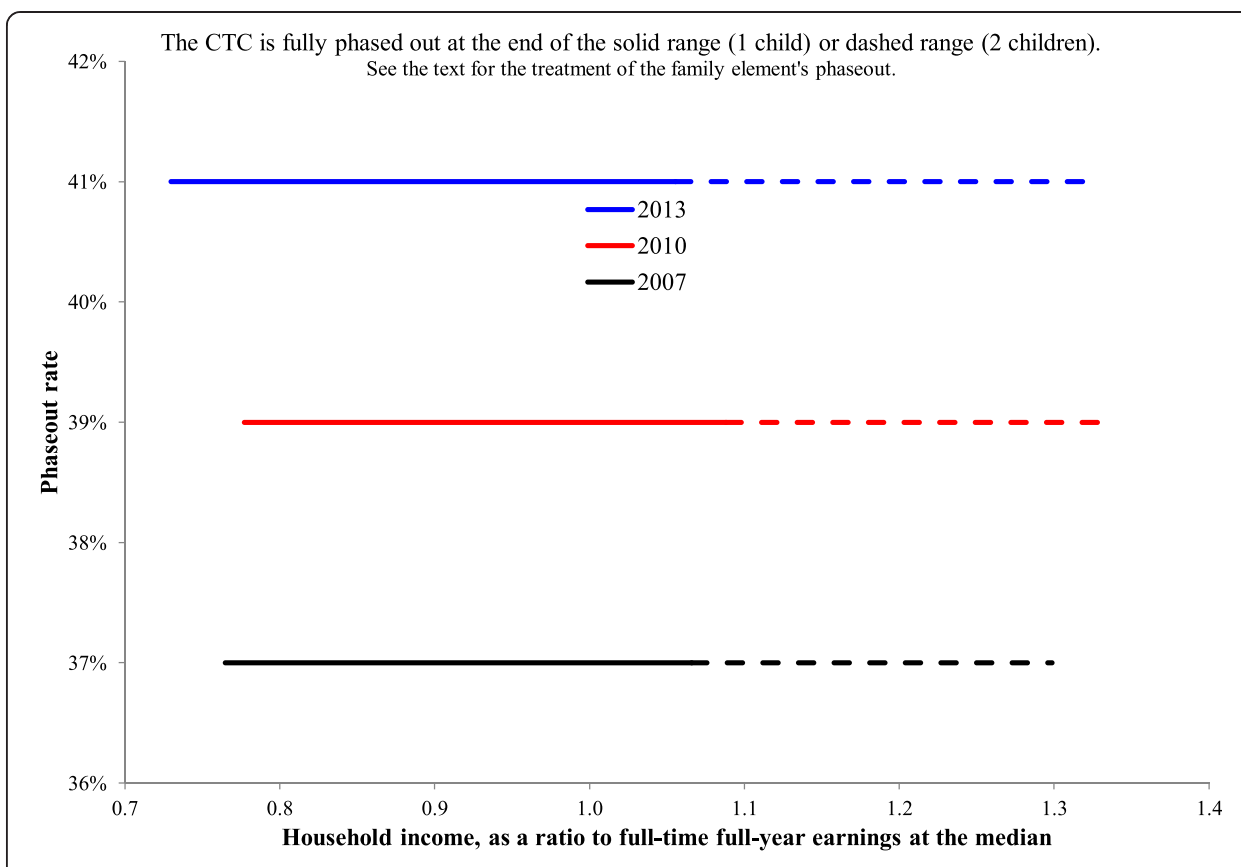

Fig. 3 U.K. Child Tax Credit phaseout ranges and rates

employment is implicitly subsidized by the threshold amounts in the NICs rules and implicitly taxed by the opportunity for unemployment benefits during weeks not working. The economic importance of these three policy parameters, represented as $U B, P T$, and $S T$ in equations (3) and (4), varies inversely with employer cost $y$. Table 1 displays each of these parameters for tax years 2010 and 2011, when some of the larger changes went into effect.

The top three rows are the NICs parameters. Both employer and employee rates increased between 2010 and 2011, which made each pound of primary and secondary threshold more

Table 1 Implicit Employment Taxes from NICs and the JSA, 2010 and 2011

\begin{tabular}{|c|c|c|c|c|}
\hline \multirow[b]{2}{*}{ Policy Parameter } & \multicolumn{2}{|c|}{ Tax Year } & \multirow[b]{2}{*}{ Change } & \multirow[b]{2}{*}{ Units } \\
\hline & 2010 & 2011 & & \\
\hline \multicolumn{5}{|l|}{$\mathrm{NICs}$} \\
\hline Employer rate & $12.8 \%$ & $13.8 \%$ & $1.0 \%$ & $\%$ of earnings above ST or PT \\
\hline Employee rate & $11.0 \%$ & $12.0 \%$ & $1.0 \%$ & \\
\hline Tax value of PT and ST & 20.5 & 26.4 & 5.9 & 2010 British pounds per week \\
\hline \multicolumn{5}{|c|}{ Job Seekers Allowance (tax adjusted) } \\
\hline & 51.8 & 51.2 & -0.6 & 2010 British pounds per week \\
\hline \multicolumn{5}{|c|}{ JSA minus Tax value of PT and ST } \\
\hline & 31.3 & 24.8 & -6.5 & 2010 British pounds per week \\
\hline & $6.5 \%$ & $5.2 \%$ & $-1.4 \%$ & Percentage of employer cost, FW \\
\hline & $6.4 \%$ & $5.3 \%$ & $-1.1 \%$ & Percentage of employer cost, WW \\
\hline \multicolumn{5}{|l|}{ Addenda } \\
\hline Basic rate for the PIT & $20.0 \%$ & $20.0 \%$ & $0.0 \%$ & Percentage of taxable income \\
\hline Employer cost & 489 & 472 & -17.5 & $\begin{array}{l}2010 \text { British pounds per } 40 \text {-hour week, } \\
\text { at the median wage }\end{array}$ \\
\hline
\end{tabular}

The JSA and ST values are net of personal income taxes at the margin, assuming the basic rate. FW ("fixed weight") estimate uses the same 2010-11 average of employer cost for both years' percentages. The VW ("variable weight") estimate uses the employer cost estimate from the same column as the reported percentage 
valuable. Moreover, the two thresholds were increased by more than $£ 25$ per week. As shown in the table's third row, the combination of these changes resulted in a 5.9-pound increase in the value (in terms of tax savings) of the primary threshold between 2010 and 2011, adjusted for inflation.

The next row is the job seekers allowance (JSA). Adjusted for inflation, it fell about one pound. The difference between the fourth and third rows is the net implicit weekly employment tax created by the JSA and NICs, holding annual income constant. It fell about seven pounds per week, adjusted for inflation. Both the JSA and ST values are adjusted for personal income taxes as specified by equation (4).

As with any employment tax, the economic importance of the employment taxes shown in Table 1 depends on their magnitudes relative to the value created by a week of work, which I measure as employer cost for a 40-h week at the median of the hourly wage distribution for full-time workers. ${ }^{22}$ The next two rows in the Table therefore express the employment taxes as a percentage of the 2010-11 average employer cost. By this measure of change, which is entirely a function of the inflation-adjusted statutory parameters, employment tax rates fell more than one percentage point between 2010 and 2011.

Real wages and real employer cost were falling during this period, which means that each pound of implicit employment tax became economically more important over time. I account for this change by using the variable-weight measures shown in the final row of the table, which use year-specific employer cost for the ratios $P T / y$ and $U B / y$. By comparison with the previous row, we see that falling real employer cost partly, but not fully, offsets the contribution of the growing value of the NICs thresholds to the weekly employment tax.

The tax-wedge equation (4) features the sum of four terms inside the parentheses. Figure 4 displays the three non-consumption-tax terms as red, blue, and green, respectively. ${ }^{23}$ For the purpose of calculating the JSA and PT/ST terms, $y$ is taken to be the weekly employer cost of the median worker (the same as in Table 1).

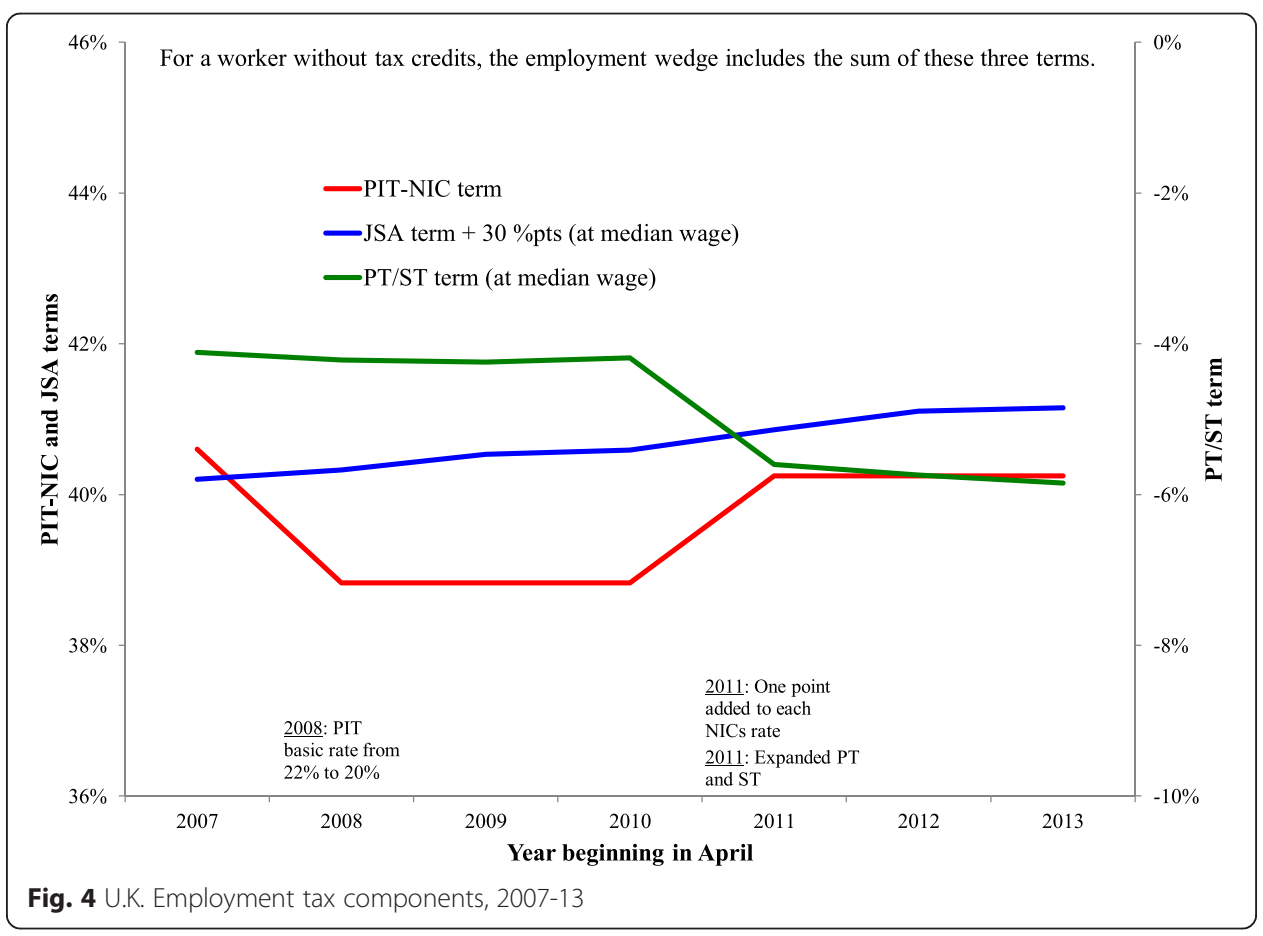


Thirty percentage points are added to the JSA term so that it can be plotted on the same scale as the PIT-NIC term. The policy parameter changes noted above are readily seen in the figure: the PIT's basic rate reduction in 2008 (red series), the 2011 addition to the NICs rates (red series), and the 2011 enhancement of the value of the PT (green series). The PIT-NIC series ends the time period essentially where it began, which leaves the net effect of the other two terms. The JSA term rises because employer costs grow less than the CPI (likely the VAT hike had something to do with that).

As with the other tax calculations in this paper, Fig. 4 does not include housing allowances for the unemployed. The changes over time would be the same if housing allowances had been included and stayed in a fixed proportion with the weekly employer cost of the median worker. See Adam and Browne (2013) for discussion of housing allowance policy changes and Appendix II for list of tax and benefit programs that are included in this paper's calculations.

Table 2's first column lists all of the tax and benefit programs that contribute to my calculation of the U.K. employment tax wedge according to equation (4). Among basic rate payers (of the personal income tax), the only reasons that the results of equation (4) vary across U.K. workers are: (a) some are having their credits phased out while others are not, (b) they have different employer cost $y$, and (c) persons who are both married and long-term unemployed may receive more JSA than the others do. Of these, only the credit phaseouts are quantitatively important for determining incentive changes over time. ${ }^{24}$ Figure 5 puts all of equation (4)'s pieces together and shows the log change in the after tax share (1-q) among married basic-rate payers, separately by employer cost and credit-phaseout status. ${ }^{25} \mathrm{~A}$ low-wage

Table 2 Tax and benefit programs included the rate calculations

\begin{tabular}{|c|c|}
\hline United Kingdom & United States \\
\hline \multicolumn{2}{|l|}{ Payroll taxes (employer and employee) } \\
\hline National Insurance Contributions & Old Age, Survivors, Disability, Medicare \\
\hline \multicolumn{2}{|l|}{ Personal Income Taxes } \\
\hline \multirow[t]{3}{*}{ Four-bracket structure } & Ordinary federal tax (without credits) ${ }^{a}$ \\
\hline & Ordinary state tax (without credits) ${ }^{a}$ \\
\hline & Exclusion of UI from taxable income \\
\hline \multicolumn{2}{|l|}{ Consumption taxes } \\
\hline VAT & $A \|^{a, b}$ \\
\hline \multicolumn{2}{|l|}{ All other ${ }^{a}$} \\
\hline \multicolumn{2}{|l|}{ Unemployment benefits } \\
\hline \multirow[t]{3}{*}{ Jobseekers Allowance } & Unemployment Insurance (UI) \\
\hline & Federal Additional Compensation \\
\hline & COBRA subsidy \\
\hline \multicolumn{2}{|l|}{ Family/Safety Net Benefits } \\
\hline Working Tax Credit & Food stamps (SNAP) \\
\hline Child Tax Credit & Medicaid $^{a}$ \\
\hline \multirow[t]{2}{*}{ Child Benefit ${ }^{c}$} & Debt discharges \\
\hline & All other ${ }^{a}$ \\
\hline
\end{tabular}

${ }^{\text {a}}$ Treated as a time-invariant parameter

${ }^{b}$ U.S. consumption taxes only appear in Fig. 7 (to the extent that they are reflected in the price deflator for Personal Consumption Expenditures)

${ }^{\mathrm{c}}$ Assumed to be independent of income and employment status for the workers represented 


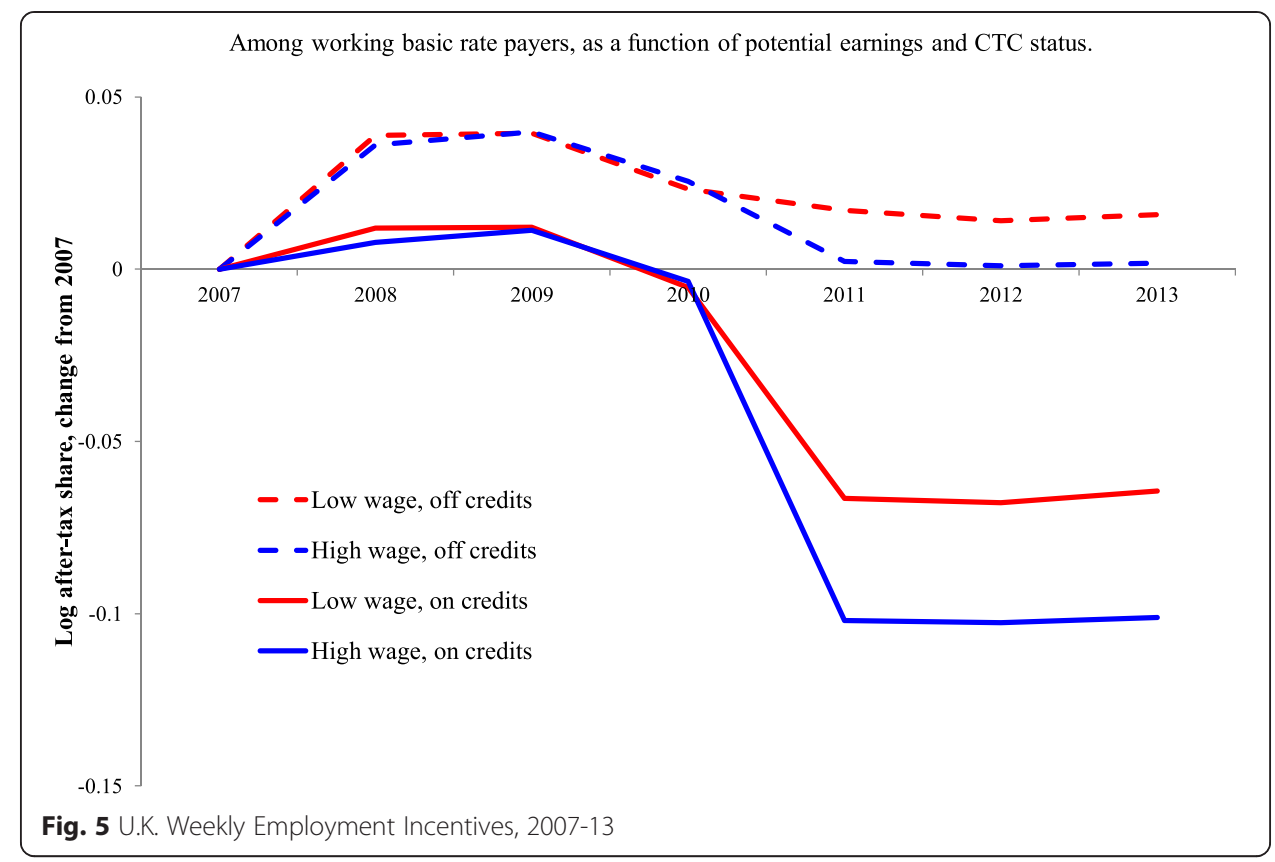

(high-wage) worker refers to one with weekly employer cost 0.4 below (above) the median worker, respectively. ${ }^{26}$

Among those with credits fully phased out (dashed series in Fig. 5), the changes are essentially the same for low- and high-wage workers. The dashed series end in 2013 about where they began because the consumption tax increase (driven by the VAT change) tends to offset the combined reduction represented as the sum of Fig. 4's three series. The low-wage dashed series finished slightly above the high-wage series because the $£ 5$ weekly reduction in the tax value of (JSA - tax value of PT and ST) is a somewhat greater percentage of employer cost for low-wage employees. Both series have a temporary increase in 2008 and 2009 because of the temporary VAT cut and because the PIT's basic rate cut was sudden, and sooner, compared with the changes in employer cost and the higher NICs rates that would come later.

The solid series shows incentive changes for "on-credits" individuals with a decision to work one week more (or less) during the year that affects the amount of their child tax credit. Specifically, on-credits individuals receive a credit if they work more, but less credit than they would receive if working less. For them, the reward to working falls significantly because the benefit reduction rate after 2010 was four points greater than it was in 2007 when their aftertax share was already as low as 20 percent. The increase in 2008 and 2009 is less than it is for those "off credits" because the benefit reduction rate increase in 2008 was offsetting the contemporaneous cut in the basic rate. Lesser employment disincentives emerge for low-wage workers because the combined value of the NICs thresholds is a nontrivial incentive for them to work and this value increased after 2007 (recall Fig. 4's green PT/ST series).

As shown in Fig. 3, the threshold for CTCs did not change in exact proportions with the median wage, which means that even a worker whose wage tracked the median might receive credits in later years but not in earlier years, or vice versa. Figure 5 omits such workers, but their incentive changes would be massive because equation (4) evaluated without credit phaseout is about 55 percent whereas the value with credit phaseout exceeds 80 percent. 
These two situations are relatively rare, though, because the thresholds did not change much relative to the median wage.

Although payroll taxes, sales taxes, and personal income taxes do not combine the income of spouses in order to determine the rate that applies, tax credits do. This by itself tends to increase the likelihood of unmarried workers to be on credits. However, because cohabiting unmarried persons are treated as married for tax credit purposes, and couples are more likely to have children, single workers are not more likely to be on credits. For example, in the tax year beginning April 2011, workers claiming tax credits as singles were only 23 percent of all adults in working families with credits (HM Revenue and Customs 2013a, Table 2.1, counting husband and wife separately). By comparison, 42 percent of adults in the U.K. were neither married nor cohabiting. ${ }^{27}$

\subsection{Comparison with previous studies}

Adam and Browne (2013) also look at changes in work incentives between 2010 and (their forecast for) 2015. Our studies have two major differences - the baseline against which policies are compared and the types of individuals considered - as well as a more subtle difference in the type of incentive(s) that we measure. On the first point, both their paper and mine note that "earnings have increased less quickly than benefit rates, which tends to make working less attractive" (Adam and Browne (2013), p. 1). Equivalently, benefit rates have increased more than wage rates: is that a policy change or not? This is merely a question of definition, and I refer to any change in benefit rates relative to wages as a policy change even if prior law would have it that way. Moreover, because benefit rates have increased relative to wages but decreased relative to the Retail Price Index (RPI, which prior law had used for indexing benefits), policy reduced the reward to work by my definition (ignoring the other statutory changes noted above).

The second difference from Adam and Browne (2013) is that my sample excludes persons not working at all during the year, whereas Adam and Browne's include them. The difference is important because "The majority of the welfare reforms involve changing the maximum amount of means-tested support that can be received by those with no other income" (Adam and Browne (2013), p. 10). Persons not working at all during a tax year may not be close to the margin for working in the short run and are thereby less interesting for short-run behavioral analysis, although excluding them altogether (as I do) errs in the opposite direction. ${ }^{28} \mathrm{I}$ look at a variety of skill levels, but, unlike Adam and Browne, not deviations from the median wage that are so large that some of the workers are still receiving working tax credits.

The reward to working an additional week examined in this paper has a lot in common with the reward to earning more per week, which Adam and Browne (2013) call the EMTR, except that the latter does not reflect foregone unemployment benefits or the value of the NICs' thresholds. As a result, they find the EMTR to be essentially constant after 2010, whereas my reward measure falls somewhat, in part because of the contribution of foregone unemployment benefits. ${ }^{29}$

Because the labor market features a rich variety of circumstances and alternative work situations, all of the tax rate measures are relevant for behavioral analysis. The additional-week measure deserves some attention for the purpose of understanding employee and employer decisions of how long to maintain a job or to endure a period of joblessness, which are decisions that are relevant for business cycle purposes. My paper is also unique in its display of year-to-year tax-wedge dynamics after 2007. 
The overall level of disincentives is not a focus of this paper or Adam and Browne's. I report comparatively higher levels $(80+$ percent is not uncommon) because of my focus on the weekly employment margin (e.g., including JSA as an implicit tax) and perhaps because of my treatment of indirect taxes. Appendix I details my measurement of, and economic assumptions about, various indirect taxes.

\section{Fiscal policy and the reward to work: the United States}

The U.S. and the U.K. have broadly similar policy types affecting the reward to work: payroll taxes, personal income taxes, consumption taxes, unemployment benefits, and safety net program benefits (recall Table 2). But they differ in terms of administrative details. The U.S. payroll tax, alternately known as "Social Security contributions" or "old age, survivors, disability, and hospital insurance contributions," is administered on a calendar-year basis - as compared to weekly (or pay period) in the U.K. - and has no analogue to the primary and secondary thresholds. The U.S. personal income tax is also administered on a calendar-year basis, and has a bracket structure broadly similar to the U.K.'s, including an annual amount that can be earned free from personal income tax.

The U.S. personal income tax includes an "Earned Income Tax Credit" (EITC) that roughly resembles the U.K.'s Working and Child Tax Credits. ${ }^{30}$ In both countries, working full-time full-year at or near the median wage would still qualify a person for a partial credit, at least if she had two qualifying children. The EITC is phased out at 7.7 percent for those without children, 16.0 percent for one-child, 21.1 percent for more than one child, as compared to 41 percent for the U.K. tax credits (Tax Policy Center 2014, rounded to the nearest tenth of a percentage point). Unlike the U.K. credit phase-out rate, the EITC phase-out rates did not change after 2007. The EITC phase-out ranges were little changed (see Mulligan 2012 for more discussion of temporary changes to EITC amounts and thresholds). Other safety net programs such as Supplemental Security Income and TANF affect tax-wedge levels, but not tax-wedge changes, because the programs did not have significant changes in their eligibility or benefit rules. For these reasons, the estimates here of the changes in U.S. work incentives after 2007 consider only food stamps, UI and related programs, health insurance assistance and the payroll tax (more on these below).

The U.S. unemployment insurance (UI) program offers weekly cash benefits to people who have lost their jobs and have as yet been unable to start a new one. The benefits expire after six months, even if the claimant continues to be out of work, although the time of expiration has been extended during recessions, especially the most recent one. Because UI is contingent on employment status, it is implicitly an employment tax, as it is in the U.K. The U.S. cashbenefit system has, at times, included additional kinds of assistance, as noted below.

The governments in both countries spend on healthcare, but in the U.S. the assistance creates disincentives because it is income and/or employment tested. Prior to 2014, the bulk of this assistance for nonelderly people came from the Medicaid program, which is jointly administered by state and federal governments. In this paper's study of incentives 2007-13, Medicaid is treated as a tax on income (and thereby employment) that is constant over time and disproportionately applicable to unmarried and low-income people.

The Department of Agriculture's food stamp program, now known as Supplemental Nutrition Assistance (SNAP), provides funds to low-income households for the purpose of buying food. SNAP benefits are potentially available to households earning less than 130 percent of the prior year poverty line, which is adjusted every fiscal year according to the rate of 
inflation. ${ }^{31}$ Traditionally, food stamps were also denied to households based on asset ownership, and the program required states to ensure that a sufficient fraction of the able-bodied adult participants were employed.

With the exception of a partial payroll tax holiday in 2011 and 2012, few American taxpayers saw a significant change in the personal income or payroll tax rules during the years 2007-13. But several safety net benefit rules were changed after 2007 in ways that created new implicit taxes on earnings and employment. Most of those rule changes related to unemployment insurance and SNAP.

A variety of legislation after 2007 temporarily and significantly added to the weekly amount of benefits and the duration of time that they could be received, and thereby temporarily increased the tax wedge on employment. ${ }^{32}$ New legislation also made it easier to claim benefits. Before the recession, the amount of the UI benefit was about half of the amount earned on the prior job, up to a state-specific cap amount that tends to be about 60 percent of the median wage. Although the benefit amounts prior to the recession tended to be proportional to earnings on the job held before the unemployment spell, the temporary benefit additions were either fixed weekly dollar amount or a fixed amount of in-kind assistance. Thus, with respect to the employment tax wedge equation (4), the UI benefit rule changes have a lot in common with an increase in the $U B$ term, which tends to be more significant for low-skill workers (they have a lesser value for employer cost $y$ ). The benefit-duration and other eligibility changes look more like an increase in $U B$ that is proportional to $y$, at least for unemployed persons receiving less than the benefit cap.

A variety of legislation in and around the recession effectively eliminated some of the longstanding barriers to SNAP eligibility and participation, leaving primarily the household income test. The time interval for the income test is not required to be the calendar year, which means that now many workers who are not poor or near poor while they are employed can qualify for food stamps during periods that they are out of work. In this regard, the food stamp rule changes have a lot in common with an increase in equation (4)'s $U B$ term. As such, the increase is more significant for low-skill workers. However, the $U B$ change associated with food stamps is less important for married workers because the program's income test considers the sum of husband and wife income.

Figure 6 shows Mulligan's (2013) results for incentive changes between 2007 and 2010 among non-elderly household heads and spouses, as a function of marital status and potential monthly earnings, and rescaled to focus on the employment margin. ${ }^{33}$ Figure 6 defines a person's potential earnings to be what each person would earn in a month of full-time work, as predicted by their demographic characteristics in a Current Population Survey sample of fulltime working non-elderly household heads and spouses. The middle group in each marital status category has weekly earnings potential of $\$ 727$ plus fringes (that is, $\$ 3,148$ per month plus fringes), which is what the median employed non-elderly household head and spouse earned in constant (fiscal year 2010) dollars during the 2007 Current Population Survey reference weeks. The other groups have weekly earnings potential of $\$ 487, \$ 595, \$ 887$, and $\$ 1084$, which differ from the middle group's potential by about $-0.4,-0.2,0.2$, and $0.4 \log$ points, respectively. The vertical axis measures the change in the tax on working in percentage points of employer cost. ${ }^{34}$ The figure also decomposes each group's employment wedge change into the contributions of five types of program expansions.

All groups had their work incentives eroded between 2007 and 2010, but the amount was less for married people. In percentage points, the changes are fairly uniform across married 


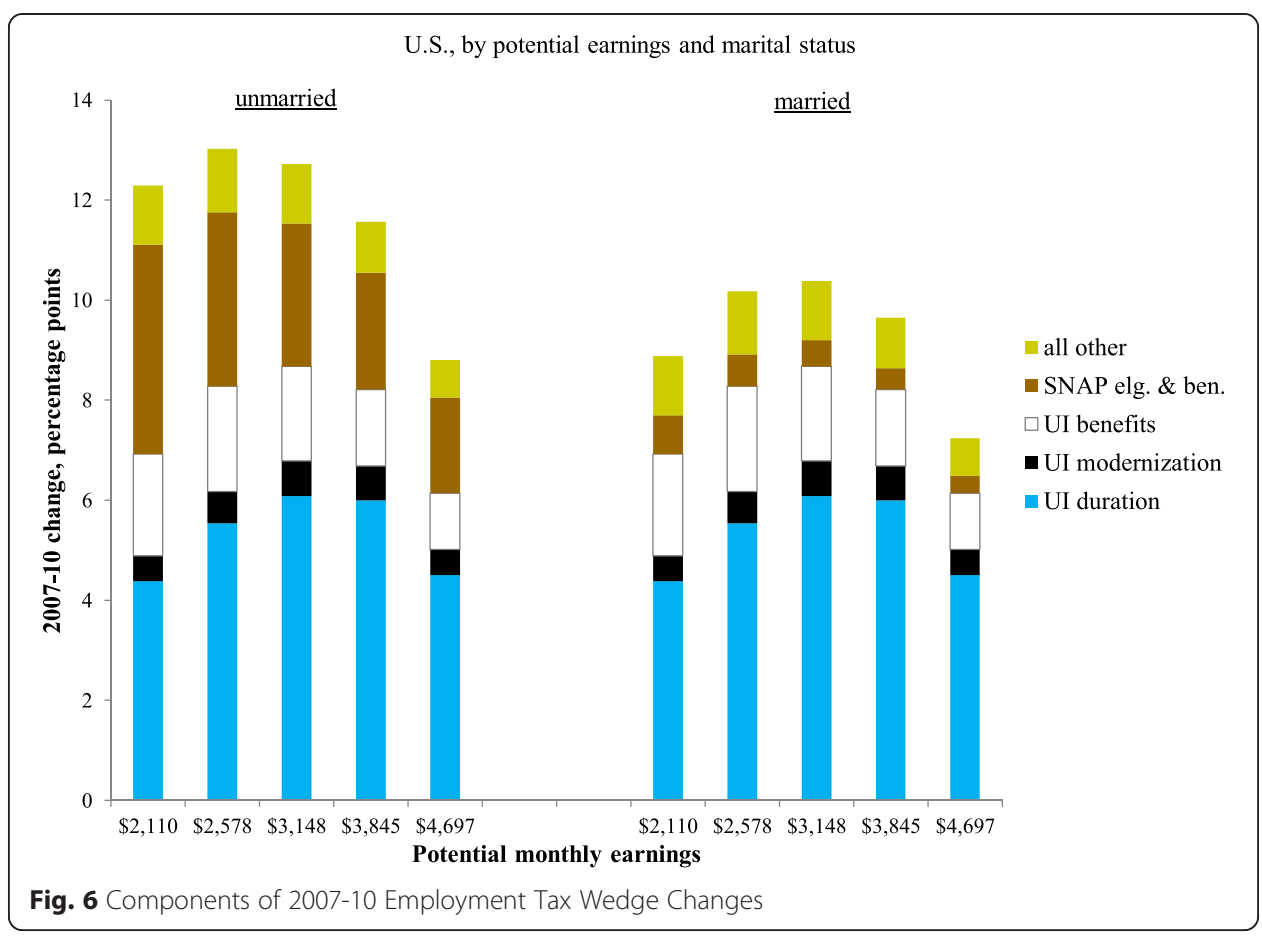

skill groups - except the top one. The changes tend to fall with skill among the unmarried, although the most skilled unmarried groups still have a change that is similar to even the less-skilled married groups. In contrast, the more meaningful distinction in the U.K. is having children, because that raises the possibility of having a partial child tax credit and the 41 percent phase-out rate that goes with it. British workers without children have incentive changes that are hardly correlated with skill (and close to zero for the full period 2007-13, as seen in Fig. 5 by comparing the two dashed series.

Some of the lesser temporary American program expansions began to expire in 2010, although a significant fraction of the temporary elevation of work disincentives remained until December 2013 when the maximum allowed duration of unemployment benefits returns to its pre-recession level. But that did not return work disincentives to their previous levels, because some of the expansions of food stamps and unemployment insurance were permanent, or at least long lived. ${ }^{35}$

More important, the 2010 Affordable Care Act began in 2014 to pay its most significant health insurance subsidies. These subsidies are both income tested and employment tested, and for both reasons have sharply increased work disincentives relative to what they would have been without the law (Mulligan 2014). ${ }^{36}$ Holding age constant, the ACA disincentives are greater for low-skill workers, even among married workers. Somewhat fewer marriedworker disincentives are created by the ACA, but not to the degree as with the temporary programs featured in Fig. 5. The disincentives are not monotone with age because older workers are more skilled but also have greater health expenses that can be subsidized (Mulligan 2015a).

\section{Conclusions}

The U.S. and the U.K. implemented different fiscal policy changes in the years following the worldwide financial crisis. The U.S. created or expanded a number of safety net programs that 
eroded the reward to work by adding to implicit employment and income taxes. The U.S. implicit tax changes were faced by a large number of workers, but the disincentives were most pronounced among unmarried workers. The U.K. changes 2007-13 were less, even for the relatively small fraction of the workforce facing the new and higher tax credit phase-out rate. The U.K. had a fiscal stimulus package too, but it involved cutting marginal tax rates on both personal income and consumption. This difference suggests that the labor market effects of stimulus packages may differ significantly in magntitude, if not direction, according to the microeconomic incentives that they create.

The U.K. tax wedge increased later during the so-called austerity period, leaving it about where it was before the recession, at least for workers not receiving tax credits. High-income taxpayers are not the focus of this paper, but the results herein show that the U.K. was unique by significantly increasing marginal income tax rates for some of them during the 2007-13 time frame. This suggests that benefit-cutting policies may increase marginal tax rates, especially if the benefit cuts primarily relate to people with relatively high employment rates or incomes. Ironically, both austerity and stimulus may create work disincentives.

Figure 7's dotted series display quarterly indexes of real employer cost for the median American worker (blue) and the median British worker (red). The purpose of showing employer cost is to show the "before-tax wage," so the British series is deflated with an adjusted CPI that reflects what the CPI would be if the value-added tax rate had remained constant. ${ }^{37}$ Both series are calculated relative to a 0.5 percent per year trend, which is the trend that is consistent with the U.S. average growth rate of total factor productivity during the four years prior to the recession. One difference between the two countries is that employer cost rose somewhat above trend in the U.S., while it fell below trend in the U.K. It is also notable that the downward trend of real British employer cost is fairly linear once we adjust for the consumption tax rate (as in Fig. 7).

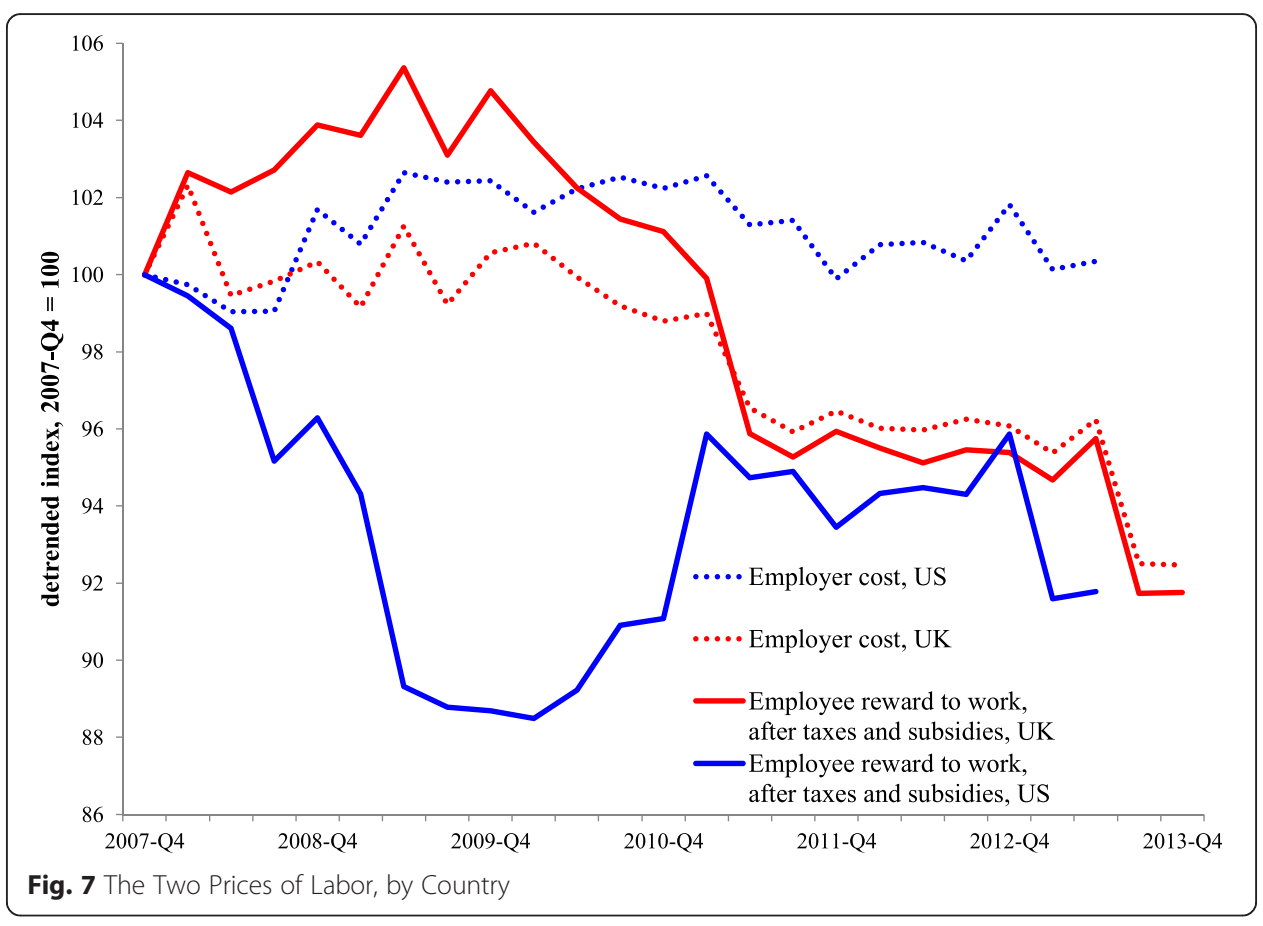


Due to taxation, some of employer cost goes to the public treasury rather than employees as a reward for their working. The two solid series are an index of the employee reward, calculated as employer cost times one minus the employment tax wedge. ${ }^{38}$ The British reward series temporarily moves above the corresponding employer cost series as the U.K. temporarily cut its VAT tax and made personal income tax rate cuts a couple of years before other types of rate increases would be implemented. Ultimately the two U.K. series finish close to each other because the employment tax wedge ultimately returns near to what it was in 2007. The U.S. follows a very different pattern, with the reward index falling far below the employer cost index in the early years of the recession.

The two countries' reward indices finish near each other: well below trend. However, because the two reward indices fall below trend for fundamentally different economic reasons, we should not expect employment changes in the two countries to have much in common. The British reward fell below trend because employer cost fell below trend, whereas the American reward fell below trend because of a tax wedge that was greater at the end of the period than it was before the recession. The tax wedge is symptomatic of redistribution, which has an aggregate income effect on labor supply of ambiguous sign and probably small magnitude. To the extent that falling employer cost in the U.K. reflects low productivity growth or an adverse change in the country's international terms of trade, it has income and substitution effects on labor supply that go in opposite directions.

In this way, country-specific employment tax wedge time series are a first of many ingredients for cross-country comparisons of labor market dynamics during and after the financial crisis. At this point, the results of this paper at least suggest the possibility that different fiscal policies in the U.S. and U.K. may have contributed to the different employment dynamics shown in Fig. 1.

\section{Endnotes}

${ }^{1}$ Both series are from the Organization for Economic Co-operation and Development (hereafter, OECD), via the St. Louis Federal Reserve's FRED database. In 2007-Q4, the U.K. and U.S. employment rates were 81.5 and 79.8 , respectively.

${ }^{2}$ Average quarterly gross flows are from Gomes (2012, Fig. 1), for 1996 through 2010. Quarterly net employment changes are from the OECD, via the St. Louis Federal Reserve's FRED database and, for comparability with Gomes, for the age 16-64 age group.

${ }^{3}$ The St. Louis Federal Reserve FRED data series UEMPMED shows that the U.S. median duration of unemployment peaked at 25 weeks in June 2010. Also note that, for example, an 18-month nonemployment spell lasting from March 2009 to September 2010 nonetheless involves positive weeks worked in both calendar years (tax years in the U.S. coincide with calendar years).

${ }^{4}$ Note that so-called "tax credits" are technically welfare spending programs in the U.K. rather than a credit to personal income taxes (Office for Budget Responsibility 2015, Tables 4.5 and 4.26). Both tax credits and personal income taxes are based on the same income concept, which this paper references as "personal income." However, tax credits are claimed jointly by couples and based on their combined income (HM Revenue and Customs 2009b), whereas the personal income tax is based on individual income (HM Government 2015c).

${ }^{5}$ I ignore integer constraints on weeks worked. Also note that many of the tax provisions are administered on a pay-period basis (e.g., weekly, biweekly or monthly). For a 
worker paid monthly, my model might be better understood as a monthly model: e.g., $w$ is monthly employer cost, $n \in[0,12]$ is number of months worked, etc.

${ }^{6} U B_{i}$ is zero for someone who is not a job seeker during the weeks that they are not employed. Job seekers allowances are taxable by the personal income tax, which is why the $U B$ term also appears inside the PIT term.

${ }^{7}$ I abstract from the fact that the personal income tax schedule varies across workers according to their nonlabor income. I also do not model council tax credits. Over the range of family situations considered in this paper, the child benefit (not to be confused with the child tax credit) is a flat amount and thereby does not create work disincentives at the margin.

${ }^{8}$ Technically, the thresholds are different for employee and employer. In fact, $P T=S T$ in 2001-10 and 2014 and within 1-3 pounds per week (out of 139 or more) in the intervening years (HM Revenue and Customs, 2014a).

${ }^{9}$ As with the U.S. Social Security contributions, the U.K. caps a significant part of its NICs, except that the U.K. caps are administered per pay period (e.g., weekly) rather than annually. The capped payments, beginning at what is known as the "upper earnings limit" (UEL) is about 75 percent more than the median weekly earnings of full-time employees. The UEL and its changes are discussed below in connection with personal income tax thresholds.

${ }^{10}$ This is a wedge between productivity $y$ (on the margin of weeks worked) and the worker's marginal benefit. In a static model such as equation (2), the latter is the marginal effect on consumption $\partial c / \partial n$. However, especially when tax rates vary over time, a worker in a dynamic model may take some of the benefit in terms of future consumption or leisure. In either model, the worker's marginal benefit can be interpreted as the marginal rate of consumption-leisure substitution (in utility) and the tax wedge (4), calculated in this paper, is properly compared with the "labor wedge" measured from household behavior (Mulligan 2012). As always, it should, for the purpose of this comparison, be noted whether the consumption expenditure ingredient in the labor wedge includes sales taxes. Also note that the tax wedge (4) includes both marginal tax rates faced by workers as well as taxes that add to employer costs.

${ }^{11} \mathrm{HM}$ Revenue and Customs (2014c, Table 2.1).

${ }^{12}$ Unemployment benefits were once indexed to the Retail Prices Index and now to the Consumer Price Index. This paper does not isolate the short-term incentive consequences of that change.

${ }^{13}$ For the dates of VAT rate changes see HM Revenue and Customs (2014b) and KPMG (2013).

${ }^{14}$ For the rate changes noted in this paragraph, see HM Revenue and Customs (2014d, 2014e).

${ }^{15}$ The upper earnings limit is analogous to the American earnings cap - a much lower NICs rate applies above the cap. Note that the upper earnings limit ( $£ 817$ per week after the cut) was significantly above median weekly earnings.

${ }^{16}$ Even after 2008, the two thresholds were not harmonized for part-year workers (see Appendix II) because the NICs are administered according to the pay interval, whereas the personal income tax is based on year-to-date earnings.

${ }^{17}$ The threshold between the 20 and 40 percent brackets is an annual income amount and is not necessarily evenly divisible by 52 weeks. At the lowest incomes, the PIT and 
NICs became less harmonized for full-year workers because the PIT's personal allowance is no longer equal to 52 times the NICs' primary threshold. This change is reflected in Fig. 2 for annual employer cost below £11,000 as 2009-11 schedules that go from 0 percent to 30 or more in multiple (albeit, barely visible) steps.

${ }^{18}$ The tax credits are paid directly to beneficiaries (HM Government 2015a) whereas personal income taxes and NICs are administered through employers.

${ }^{19}$ The quarterly time series for the median hourly wage among full-time employees is from Office for National Statistics (2014a). See also HM Revenue and Customs (2009a), which gives an example of a couple each working part-time schedules throughout the tax year but nonetheless receiving zero WTC because their annual income, although low by the standards of the median family, is still too high.

${ }^{20}$ The child tax credits are not contingent on work. In principle, the working tax credits (WTCs) are withheld during weeks not at work (with an exception for a fourweek spell in between jobs). As a result, if annual income qualifies a worker for a positive WTC, the WTC has both a positive and negative effect on the weekly employment tax wedge. The positive-tax effect comes from the effect of a week's employment on annual income and therefore the weekly amount of WTC to be received during times of employment. The magnitude of the positive tax effect depends on the phase-out rate and the number of weeks during the year the person is at work (i.e., equation (4) itself would depend on $n$ ). The negative-tax effect comes from the withholding of WTC payments during weeks not employed and, for the reasons noted below, is not relevant for my calculations.

${ }^{21}$ For simplicity, Fig. 2 assumes that, for all years $2007-13$, the phaseout of the family element of the CTC begins exactly at the income level for which the rest of the CTC is exhausted. In practice, this harmonization of phaseout ranges did not take effect until 2012. Before that, there were incomes for which all of the child element, but none of the family element, was phased out. Note that Fig. 2's simplifying assumption is of little quantitative significance because the amount of the family element is less than one quarter of the full CTC amount.

${ }^{22}$ Weekly employer cost is taken to be $40 *$ (median hourly wage) + (weekly employer NICs, accounting for the secondary threshold).

${ }^{23}$ The (2010 and 2011 values of the) sum of Fig. 4's blue and green series is shown in the last row of Table 1.

${ }^{24}$ Item (c) refers to the income-based JSA, which is examined in Appendix II. The rest of the paper considers only the contributory JSA, the amount of which does not depend on marital status (HM Government 2015b).

${ }^{25}$ For some behavioral analysis, the JSA's should be discounted relative to the PT because the PT affects all workers, whereas only some of those out of work receive a JSA. During this period, however, changes in JSA per capita were very close in magnitude to changes in both employment and unemployment (BBC 2015, Office for National Statistics 2014b). Also note that the level of $q$ matters for Fig. 5, which means that the magnitude of the changes would tend to be greater if housing allowances were included in my estimates.

${ }^{26}$ For low-wage workers, the withholding of WTC during weeks of nonemployment may be relevant, even while it is not included in my calculations. There are a couple of reasons why it might not be relevant: (a) the worker's WTC is zero because annual family income is 
at least 80 percent of full-time full-year earnings at the median hourly wage, (b) the worker's spell between jobs is four weeks or less, or (c) the worker does not or cannot claim WTC even during weeks of employment (e.g., because the spouse already claims the credit). Moreover, even when relevant, the withholding of WTC hardly effects incentive changes over time because the WTC amount was not significantly changed relative to wages. Beginning in 2013, the child benefit (not to be confused with tax credits) began to be phased out based on the annual income of the adult receiving it. This is a new disincentive for workers with annual incomes between $£ 50,000$ and $£ 60,000$, which is more than twice the annual income obtained by working full-time full-year at the median hourly wage (among full-time workers). As a result, the new disincentive, which can add significantly more than ten percentage points to the marginal tax rate, depending on the number of children, is not reflected in any of this paper's exhibits.

${ }^{27}$ The numerator of the 58 percent (which is 100 minus the 42 percent cited in the text) is from Office for National Statistics (2012) and the denominator from Office for National Statistics (2013, ages 20 and over, plus 4/5ths of persons aged 15-19). In the last year that couples jointly filed personal tax returns (1989), 72 percent of persons filing returns (counting husbands and wives separately) were filing unmarried returns (HM Revenue and Customs 2015). The same sources indicate that 8.7 million adults received tax credits in, say, 2011-12, whereas 30.8 million filed personal income tax returns.

${ }^{28}$ It is also difficult to know what a person not working during the tax year would have earned if he had worked. This problem is alleviated, but not absent, in samples of workers; we do not know for sure what a worker would have earned if he had gone back to work a week earlier or had left employment a week later.

${ }^{29}$ Adam and Browne (2013), as well as OECD (2012), also calculate the reward to working a full tax year rather than not working at all. An increase in, say, the personal allowance does not affect the reward to working an additional week except for the small group of people who are working so little during the year that they have not used up their personal allowance. Or consider a person earning, for the tax year, in the 20-percent bracket with an income just below the threshold for the 40-percent bracket. A reduction in that threshold hardly affects the reward to working at all during the tax year but doubles the disincentive from the income tax for working an additional week.

${ }^{30}$ For the purposes of considering non-poor workers, the CTC is a better analogy to the EITC because neither is withheld during weeks not at work. In both countries, the income concept for tax credits is essentially the same as the income subject to personal income tax, even though the U.K.'s tax credits are administered as separate benefit programs.

${ }^{31}$ The federal government's fiscal year is the year ending September 30 . The fiscal year indicates when safety net benefit program parameters are reset, and the nature of the federal budgeting, but not the time frame for performing the income test.

${ }^{32}$ The temporary benefit and eligibility rules for UI and food stamps are too numerous to itemize here: see Mulligan (2012), especially chapter 3.

${ }^{33}$ The tax rates shown in Mulligan (2013) are composites of employment (2/3) and weekly hours (1/3) tax rates. This paper is focused on employment tax rates only, so Fig. 6 reports just the employment component of Mulligan (2013)'s composite. Because hardly any of the composite tax rate changes come from weekly-hours tax rate changes, the results in Fig. 6 are essentially Mulligan (2013, Fig. 7) scaled by $3 / 2$.

${ }^{34}$ That is, it is the absolute change in $q$ as represented in equation (4). 
${ }^{35}$ Food stamp work requirements have been repeatedly waved since 2009 (Mulligan 2015b). Other food stamp eligibility expansions are permanent in that new legislation would be required for them to return to the pre-recession eligibility rules.

${ }^{36}$ The ACA disincentives more than offset the incentives that were created by the expiration of the aforementioned temporary assistance programs.

${ }^{37}$ The adjusted CPI is the official CPI divided by one plus the consumption tax rate.

${ }^{38}$ In the notation of the paper, the employee reward is $(1-q) y$. The paper calculates two $q$ series for the median worker in each country: on credits versus off credits for the U.K. and single versus married for the U.S. For the purpose of preparing Fig. 7, a fixed-weighted average of the two series are used according to the proportions of each situation in the adult population.

${ }^{39}$ Fuel and tobacco duty changes are the only non-VAT indirect tax rate changes considered in this paper. According to Institute for Fiscal Studies (2015), a few other changes occurred 2008-13: alcohol duties increased by $6 \%$ in real terms in 2008 and then $2 \%$ in real terms each subsequent year until 2013 (partial reversals followed in 2013), a 2011 change in the carbon price floor for electricity generation, a new stamp duty land tax rate on large properties, and 2012 changes to vehicle excise duties. These changes are of less aggregate importance than those for fuel and tobacco.

${ }^{40}$ For fuel, I (a) took the April 2007 retail price, £0.928/liter, reported by Vial (2012), (b) backed out the non-VAT part of the retail price using the statutory VAT rate of $17.5 \%$, and (c) subtracted the specific excise rate of $£ 0.5152 /$ liter. For cigarettes, HM Revenue and Customs (2013b) reports a non-tax revenue per typically-priced pack of $£ 0.9255$ on March 31 2007.

${ }^{41}$ Note that sellers above the VAT-registration threshold pay the statutory rate on all of their sales, even the sales below the threshold (Keen and Mintz 2004, Onji 2009). In theory, sellers might optimally restrict their size to remain below the threshold, thereby generating no VAT revenue but nonetheless having added marginal costs that reflect the existence of a VAT. The small-seller exemption is just an example of a more general phenomenon: that the marginal tax rate can exceed the average tax due to avoidance and noncompliance behaviors.

${ }^{42}$ In other words, a person reducing leisure would pay the statutory VAT rate on some of his additional consumption, but not all of it. In this case, a revenue-based measure of the consumption tax rate (Mendoza, Razin and Tesar 1994, Immervoll, et al. 2007, Adam 2005) will more accurately represent incentives than the full statutory rate does.

${ }^{43} 0.066$ is $0.86 * 0.44 *$ (statutory VAT rate) for $2003-7$. Recall from above that 0.86 is the ratio of 2003-7 non-VAT revenue to VAT revenue. By using the 0.44 revenue ratio, I am assuming that the non-VAT indirect taxes do not have the small-seller exemption (or other compliance and enforcement features that create marginal costs without obtaining revenue). Because the revenue ratio is VAT revenue divided by total consumption, 0.066 is effectively indirect tax revenue divided by total consumption.

${ }^{44}$ The income-based JSA is also available to persons with weekly earnings (during periods of employment) less than about $£ 150$, which is far below the range of earnings scenarios considered in this paper.

\section{Appendix I: indirect tax rate changes in the U.K.}

This appendix describes the paper's treatment of non-VAT indirect taxes and VAT exemptions for the purposes of measuring labor market tax wedges. Almost as much indirect 
tax revenue is obtained from non-VAT taxes as from VAT taxes. On average between 2003 and 2007 (the five years prior to the crisis), fuel duty revenue was 32 percent of VAT revenue. Tobacco duty revenue was 11 percent. "Other" revenue, including alcohol duties and other excise taxes, was 44 percent, for a combined total of 86 percent of VAT revenue. Moreover, the rates of the two largest excise taxes - fuel and tobacco - changed significantly. ${ }^{39}$

The excise taxes tend to be multiplicative with the VAT. Suppose, for example, that a pack of cigarettes would cost $£ 3$ at retail without indirect taxes. Assuming $100 \%$ pass-through, a $£ 2$-per-pack specific excise tax (paid somewhere in the supply chain) would by itself make the retail price $£ 5$. Adding a $20 \%$ VAT, to be paid by the seller, would make the total price $£ 6$, whereas the VAT-inclusive price absent excise tax would be $£ 3.60$. In the case of tobacco, there is also an ad valorem excise tax, which is multiplicative as well because it includes both the specific tax and the VAT tax as part of its base.

Given the VAT's multiplicative implementation, the relative prices of excisable goods can be calculated without regard for the VAT. For fuel (specifically, unleaded petrol purchased at retail) and tobacco (specifically, a typically-priced pack of cigarettes) in April 2007, I calculated the ratio of the specific excise rate to the non-tax revenue per unit sold at retail. ${ }^{40}$ This ratio was made into a monthly time series according to proportional changes over time in the CPI-adjusted excise rate applicable on the first day of the month. One was added to transform the ratio into a pricing factor. The tobacco-pricing factor was adjusted again by multiplying by one plus the applicable $a d$ valorem tobacco excise tax. Tax-year averages of the fuel and tobacco pricing factors are displayed in Fig. 8. The tobacco factor rises, especially after 2009, whereas the fuel factor falls. Both changes are due to changes in the legislated specific tax rates relative to the CPI.

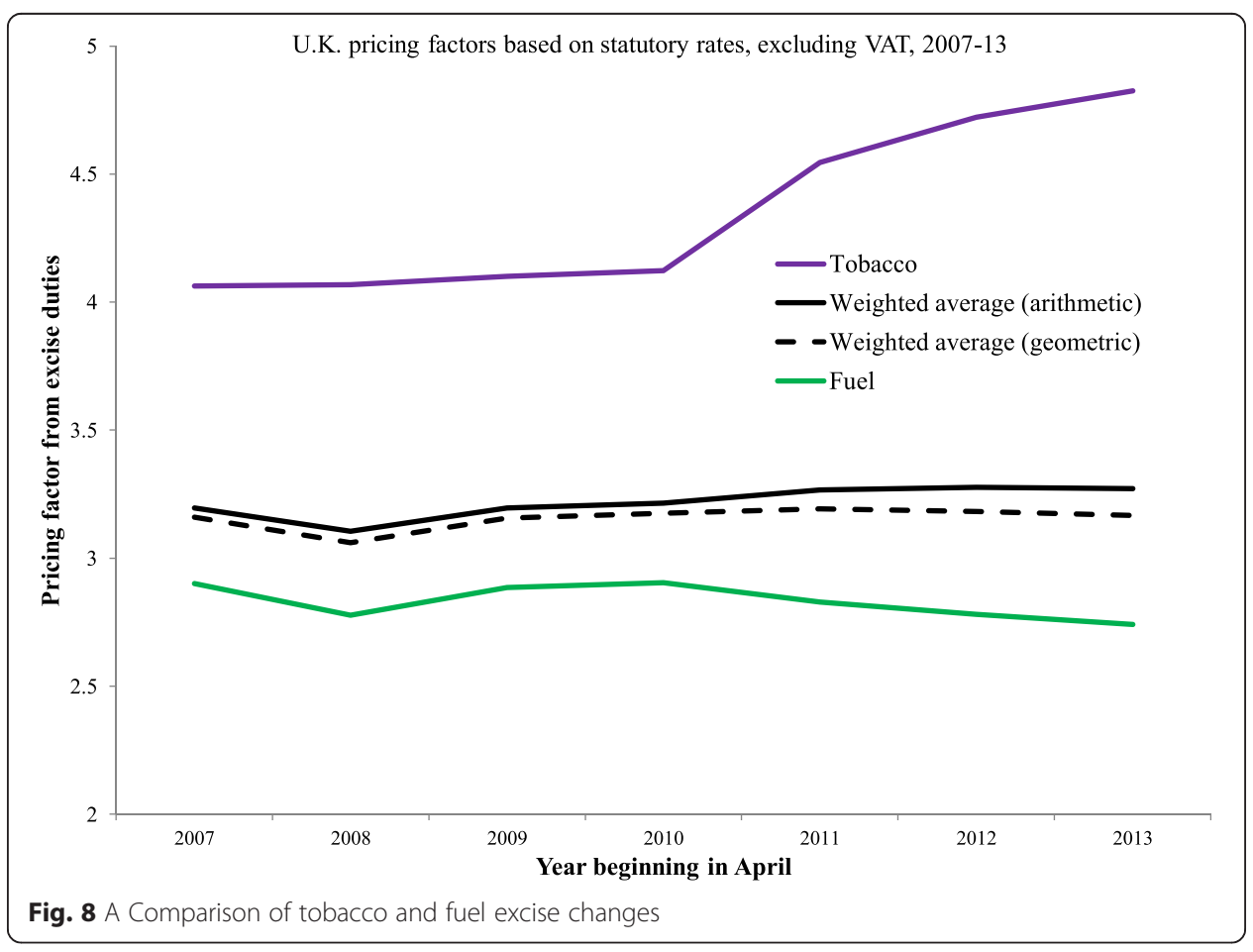


Because the purpose of this paper is to calculate tax rates that would be relevant for national labor market analysis, I have calculated fuel-tobacco averages. The averages are shown in black in Fig. 8, both using the relative excise revenue in 20037 as weights. These averages suggest that the tobacco increases approximately offset the fuel decreases from the perspective of taxing consumption relative to leisure. Based on this finding, and in order to avoid introducing unimportant complications in the tax-wedge estimation methodology, I therefore treat the non-VAT indirecttax rates as constant over time.

Putting aside non-VAT taxes for the moment, using statutory VAT rates as my model (2)'s consumption tax rate would exaggerate the amount of revenue actually obtained by the U.K.'s VAT. The OECD (2014, Table 3.A3.1) finds that the latter has been 44 percent of the former for each of the years 2008-12. Part of the discrepancy results from the exemption of small businesses from VAT and from noncompliance. If these were the entire discrepancy, and compliance were greater for large businesses than for small, then the pricing impact of the VAT could either be more or less than that of a full-compliance exemption-free VAT with the same statutory rate. ${ }^{41}$ But another part of the discrepancy results from the VAT-exemption of entire markets, such as health care and financial services, and reduced statutory rates in other markets. If market exemptions and rate reductions were the only reason that VAT revenue was low relative to the statutory standard rate, then revenue would be a better indicator than the statutory standard rate of the wedge created by the VAT between leisure and total consumption. ${ }^{42} \mathrm{HM}$ Revenue and Customs (various issues) has measured the degree to which the discrepancy derives from market exemptions and rate reductions, and found for 2007 through 2013 that actual revenue is about 63 percent of what it would be if there had not been market exemptions and rate reductions. This paper therefore takes the VAT rate to be 63 percent of the statutory standard rate.

The overall sales tax rate referenced in the text combines the time-varying VAT rate (including the factor of 0.63 ) and a constant rate of 6.6 percent for the other indirect taxes according to the formula $(5)^{43}$ :

$$
1+\tau_{c}=[1+0.63(\text { statutory VAT rate })][1+0.066]
$$

With the statutory standard VAT rate equal to $15,17.5$, and 20 , respectively, $\tau_{c}$ is 16.7 , 18.4, and 20.1, respectively. Table 3 displays $\tau_{c}$ and all of the other U.K. tax parameters needed to calculate the overall employment tax on a quarterly basis according to equation (4).

\section{Appendix II: additional perspectives on U.K. employment tax wedge changes}

Figure 2 shows how U.K. tax law changes served to harmonize the personal income tax (PIT) brackets with the national insurance contribution (NICs) brackets, from the perspective of a full-year worker. However, Fig. 9 shows that gaps between the brackets remain for part-year workers because the NICs are administered on a pay-period basis, whereas PIT is based on tax-year income.

The paper shows significantly different employment tax wedge changes for married versus unmarried workers in the U.S. Holding constant credit status (emphasized in the main text), no such difference is seen in the U.K. largely because the NICs, the basic PIT, the 
Table 3 U.K. Tax Parameters. For use in equation (4). Pounds are not inflation adjusted

\begin{tabular}{|c|c|c|c|c|c|c|c|c|c|c|c|}
\hline \multicolumn{5}{|c|}{ NICs parameters } & \multirow{2}{*}{$\begin{array}{l}y \\
\text { Employer cost }\end{array}$} & \multicolumn{2}{|l|}{$\tau_{i}$} & \multirow{2}{*}{$\begin{array}{l}\text { UB } \\
\text { Unempl. Benefit }\end{array}$} & \multirow{2}{*}{$\begin{array}{l}T_{c} \\
\text { Consumption tax rate }\end{array}$} & \multicolumn{2}{|c|}{ Overall wedge $q$ (weekly employment) } \\
\hline Quarter & PT & ST & Employer rate $T_{f}$ & Employer rate $\tau_{e}$ & & PIT basic & CTC BRR & & & Off credits & On credits \\
\hline 2007-Q1 & $£ 97$ & $£ 97$ & $12.8 \%$ & $11.0 \%$ & $£ 445$ & $22.0 \%$ & $37.0 \%$ & & $18.8 \%$ & & \\
\hline 2007-Q2 & $£ 100$ & $£ 100$ & $12.8 \%$ & $11.0 \%$ & $£ 446$ & $22.0 \%$ & $37.0 \%$ & $£ 59.15$ & $18.8 \%$ & $55.2 \%$ & $79.5 \%$ \\
\hline 2007-Q3 & $£ 100$ & $£ 100$ & $12.8 \%$ & $11.0 \%$ & $£ 449$ & $22.0 \%$ & $37.0 \%$ & $£ 59.15$ & $18.8 \%$ & $55.2 \%$ & $79.5 \%$ \\
\hline 2007-Q4 & $£ 100$ & $£ 100$ & $12.8 \%$ & $11.0 \%$ & $£ 451$ & $22.0 \%$ & $37.0 \%$ & $£ 59.15$ & $18.8 \%$ & $55.1 \%$ & $79.4 \%$ \\
\hline 2008-Q1 & $£ 100$ & $£ 100$ & $12.8 \%$ & $11.0 \%$ & $£ 464$ & $22.0 \%$ & $37.0 \%$ & $£ 59.15$ & $18.8 \%$ & $55.0 \%$ & $79.4 \%$ \\
\hline 2008-Q2 & $£ 105$ & $£ 105$ & $12.8 \%$ & $11.0 \%$ & $£ 460$ & $20.0 \%$ & $39.0 \%$ & $£ 60.50$ & $18.8 \%$ & $53.7 \%$ & $79.4 \%$ \\
\hline 2008-Q3 & $£ 105$ & $£ 105$ & $12.8 \%$ & $11.0 \%$ & $£ 468$ & $20.0 \%$ & $39.0 \%$ & $£ 60.50$ & $18.8 \%$ & $53.6 \%$ & $79.3 \%$ \\
\hline 2008-Q4 & $£ 105$ & $£ 105$ & $12.8 \%$ & $11.0 \%$ & $£ 474$ & $20.0 \%$ & $39.0 \%$ & $£ 60.50$ & $18.2 \%$ & $53.4 \%$ & $79.2 \%$ \\
\hline 2009-Q1 & $£ 105$ & $£ 105$ & $12.8 \%$ & $11.0 \%$ & $£ 472$ & $20.0 \%$ & $39.0 \%$ & $£ 60.50$ & $17.0 \%$ & $52.9 \%$ & $79.0 \%$ \\
\hline 2009-Q2 & $£ 110$ & $£ 110$ & $12.8 \%$ & $11.0 \%$ & $£ 488$ & $20.0 \%$ & $39.0 \%$ & $£ 64.30$ & $17.0 \%$ & $53.1 \%$ & $79.1 \%$ \\
\hline 2009-Q3 & $£ 110$ & $£ 110$ & $12.8 \%$ & $11.0 \%$ & $£ 482$ & $20.0 \%$ & $39.0 \%$ & $£ 64.30$ & $17.0 \%$ & $53.2 \%$ & $79.1 \%$ \\
\hline 2009-Q4 & $£ 110$ & $£ 110$ & $12.8 \%$ & $11.0 \%$ & $£ 493$ & $20.0 \%$ & $39.0 \%$ & $£ 64.30$ & $17.0 \%$ & $53.1 \%$ & $79.1 \%$ \\
\hline 2010-Q1 & $£ 110$ & $£ 110$ & $12.8 \%$ & $11.0 \%$ & $£ 491$ & $20.0 \%$ & $39.0 \%$ & $£ 64.30$ & $18.8 \%$ & $53.8 \%$ & $79.4 \%$ \\
\hline 2010-Q2 & $£ 110$ & $£ 110$ & $12.8 \%$ & $11.0 \%$ & $£ 494$ & $20.0 \%$ & $39.0 \%$ & $£ 65.45$ & $18.8 \%$ & $53.9 \%$ & $79.5 \%$ \\
\hline 2010-Q3 & $£ 110$ & $£ 110$ & $12.8 \%$ & $11.0 \%$ & $£ 492$ & $20.0 \%$ & $39.0 \%$ & $£ 65.45$ & $18.8 \%$ & $53.9 \%$ & $79.5 \%$ \\
\hline 2010-Q4 & $£ 110$ & $£ 110$ & $12.8 \%$ & $11.0 \%$ & $£ 495$ & $20.0 \%$ & $39.0 \%$ & $£ 65.45$ & $18.8 \%$ & $53.9 \%$ & $79.5 \%$ \\
\hline 2011-Q1 & $£ 110$ & $£ 110$ & $12.8 \%$ & $11.0 \%$ & $£ 497$ & $20.0 \%$ & $39.0 \%$ & $£ 65.45$ & $20.5 \%$ & $54.5 \%$ & $79.8 \%$ \\
\hline 2011-Q2 & $£ 139$ & $£ 136$ & $13.8 \%$ & $12.0 \%$ & $£ 493$ & $20.0 \%$ & $41.0 \%$ & $£ 67.50$ & $20.5 \%$ & $54.8 \%$ & $81.2 \%$ \\
\hline 2011-Q3 & $£ 139$ & $£ 136$ & $13.8 \%$ & $12.0 \%$ & $£ 493$ & $20.0 \%$ & $41.0 \%$ & $£ 67.50$ & $20.5 \%$ & $54.8 \%$ & $81.2 \%$ \\
\hline 2011-Q4 & $£ 139$ & $£ 136$ & $13.8 \%$ & $12.0 \%$ & $£ 502$ & $20.0 \%$ & $41.0 \%$ & $£ 67.50$ & $20.5 \%$ & $54.7 \%$ & $81.2 \%$ \\
\hline 2012-Q1 & $£ 139$ & $£ 136$ & $13.8 \%$ & $12.0 \%$ & $£ 502$ & $20.0 \%$ & $41.0 \%$ & $£ 67.50$ & $20.5 \%$ & $54.7 \%$ & $81.2 \%$ \\
\hline 2012-Q2 & $£ 146$ & $£ 144$ & $13.8 \%$ & $12.0 \%$ & $£ 506$ & $20.0 \%$ & $41.0 \%$ & $£ 71.00$ & $20.5 \%$ & $54.9 \%$ & $81.2 \%$ \\
\hline 2012-Q3 & $£ 146$ & $£ 144$ & $13.8 \%$ & $12.0 \%$ & $£ 510$ & $20.0 \%$ & $41.0 \%$ & $£ 71.00$ & $20.5 \%$ & $54.9 \%$ & $81.2 \%$ \\
\hline
\end{tabular}


Table 3 U.K. Tax Parameters. For use in equation (4). Pounds are not inflation adjusted (Continued)

\begin{tabular}{|c|c|c|c|c|c|c|c|c|c|c|c|}
\hline 2012-Q4 & $£ 146$ & $£ 144$ & $13.8 \%$ & $12.0 \%$ & $£ 515$ & $20.0 \%$ & $41.0 \%$ & $£ 71.00$ & $20.5 \%$ & $54.8 \%$ & $81.2 \%$ \\
\hline 2013-Q1 & $£ 146$ & $£ 144$ & $13.8 \%$ & $12.0 \%$ & $£ 515$ & $20.0 \%$ & $41.0 \%$ & $£ 71.00$ & $20.5 \%$ & $54.8 \%$ & $81.2 \%$ \\
\hline 2013-Q2 & $£ 149$ & $£ 148$ & $13.8 \%$ & $12.0 \%$ & $£ 524$ & $20.0 \%$ & $41.0 \%$ & $£ 71.70$ & $20.5 \%$ & $54.7 \%$ & $81.2 \%$ \\
\hline 2013-Q3 & $£ 149$ & $£ 148$ & $13.8 \%$ & $12.0 \%$ & $£ 505$ & $20.0 \%$ & $41.0 \%$ & $£ 71.70$ & $20.5 \%$ & $54.9 \%$ & $81.2 \%$ \\
\hline 2013-Q4 & $£ 149$ & $£ 148$ & $13.8 \%$ & $12.0 \%$ & $£ 509$ & $20.0 \%$ & $41.0 \%$ & $£ 71.70$ & $20.5 \%$ & $54.9 \%$ & $81.2 \%$ \\
\hline
\end{tabular}




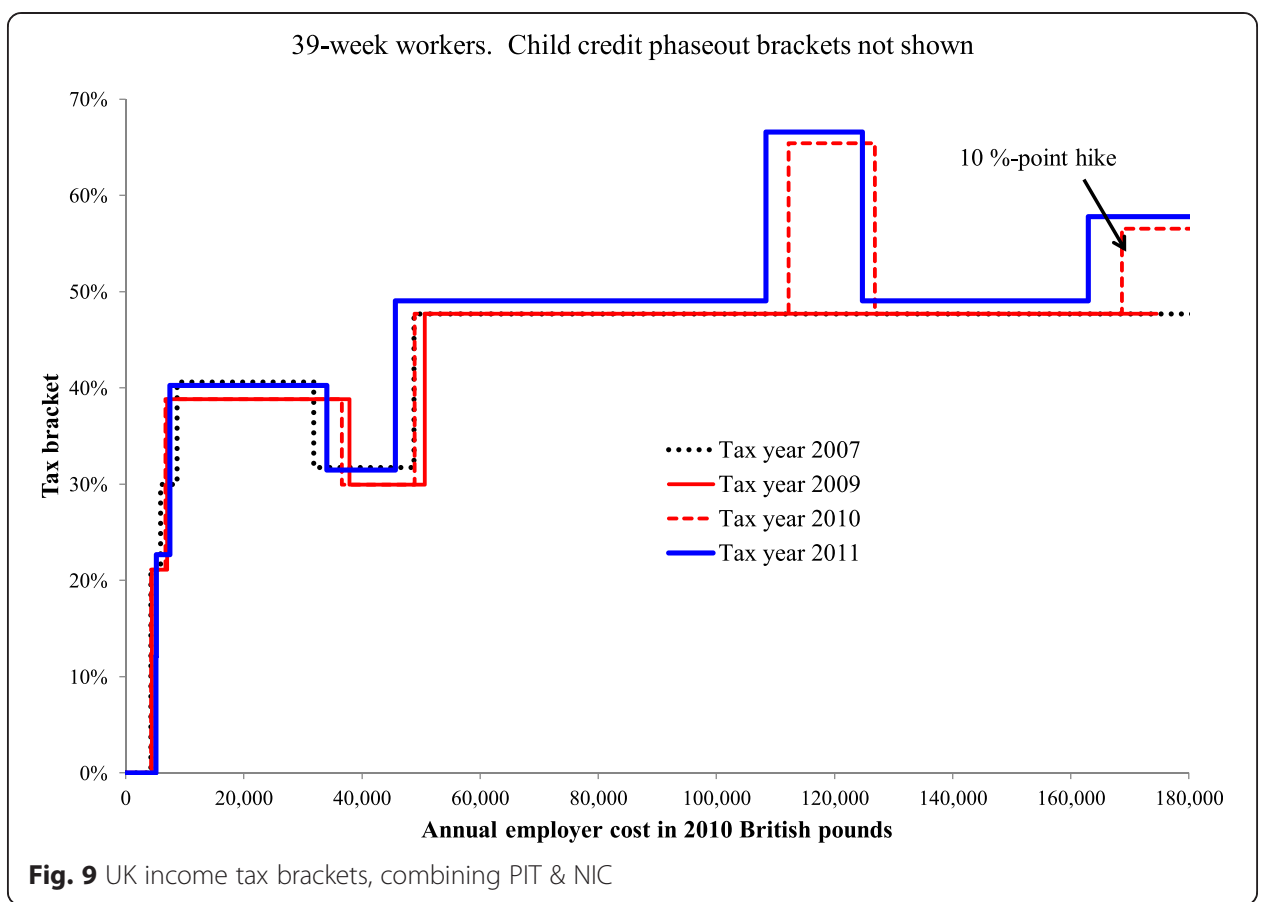

contributory JSA, and the VAT are not administered on the basis of household composition (recall footnote 4). Persons who have been unemployed more than 26 weeks potentially receive an income-based job seekers allowance, which pays more to married than to unmarried job seekers if the spouse is working less than $24 \mathrm{~h}$ per week. ${ }^{44}$ But, as shown in Fig. 10, this provision by itself has not changed enough to produce significantly different (in the economic sense) U.K. incentive dynamics by type of JSA, which is related to marital status.

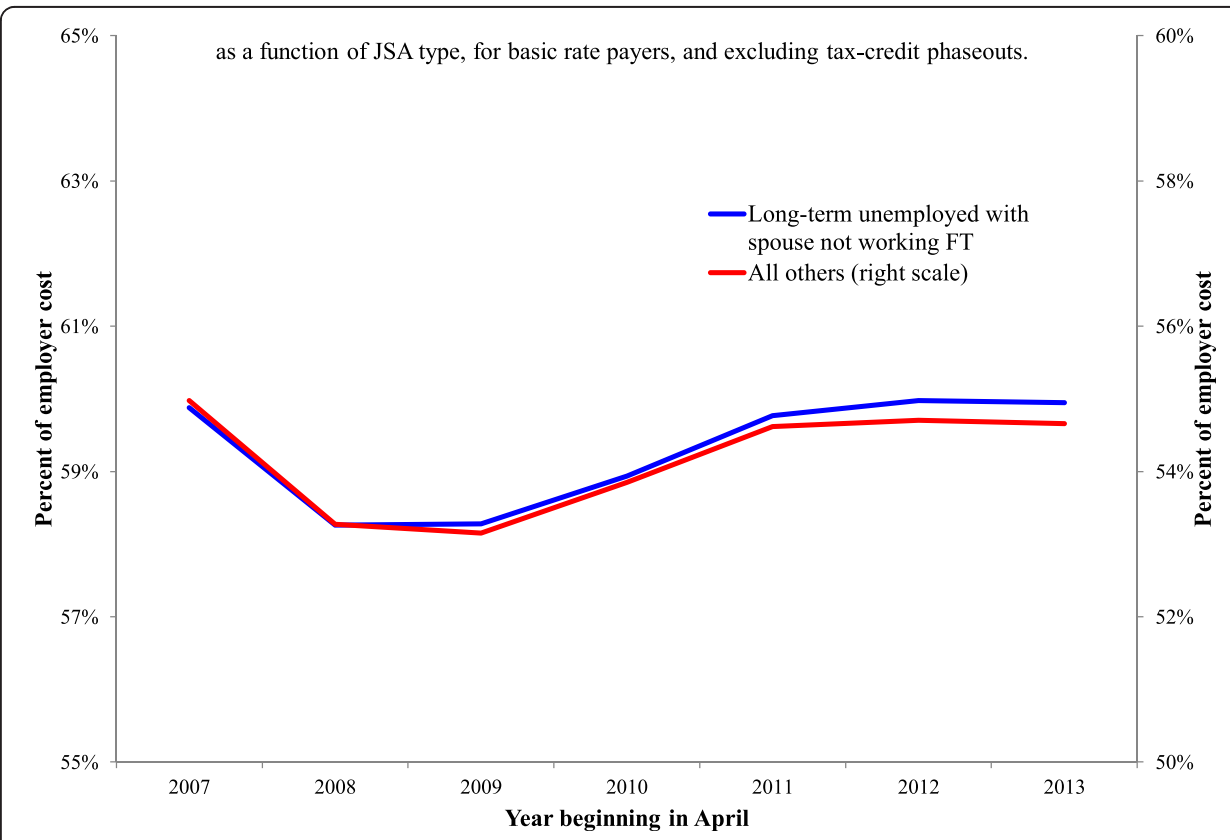

Fig. 10 U.K. employment tax wedge, 2007-13 


\section{Competing interests}

The IZA Journal of Labor Policy is committed to the IZA Guiding Principles of Research Integrity. The author declares that he has observed these principles.

\section{Acknowledgements}

I appreciate the financial support of the George J. Stigler Center for the Study of the Economy and the State and discussions with Kyle Herkenhoff, and comments from David Neumark and an anonymous referee.

Responsible editor: David Neumark

Received: 18 March 2015 Accepted: 22 August 2015

Published online: 10 December 2015

\section{References}

Adam S (2005) Measuring the Marginal Efficiency Cost of Redistribution in the UK. Institute for Fiscal Studies Working Paper, no. 05/14

Adam S, Browne J (2013) Do the UK Government's welfare reforms make work pay? IFS working paper, no. 13/26 BBC (2015) Economy Tracker: Unemployment. http://www.bbc.com/news/10604117 (accessed February 8, 2015).

Brewer M, Browne J, Hood A, Robert J, Sibieta L (2013) The Short- and Medium-term Impacts of the Recession on the UK Income Distribution. Fisc Stud 33(2):179-201

Gomes P (2012) Labour market flows: Facts from the United Kingdom. Labour Econ 19(2):165-75

HM Government (2015a) Tax credits: your payment dates. gov.uk. https://www.gov.uk/when-is-your-next-tax-creditspayment (accessed February 13, 2015).

HM Government (2015b) Benefits \& credits: Jobseeker's Allowance (JSA). gov.uk. https://www.gov.uk/jobseekersallowance/print (accessed July 6, 2015).

HM Government (2015c) Income Tax. gov.uk. https://www.gov.uk/income-tax/overview (accessed February 13, 2015)

HM Revenue and Customs (2009a) Calculation of Entitlement. Tax Credits Technical Manual. https://web.archive.org/ web/20090714131643/http://www.hmrc.gov.uk/manuals/tctmanual/TCTM07000.htm (accessed August 15, 2015).

HM Revenue and Customs (2009b) Claims and Notification. Tax Credits Technical Manual. https://web.archive.org/web/ 20090714131633/http://www.hmrc.gov.uk/manuals/tctmanual/TCTM06000.htm (accessed August 15, 2015).

HM Revenue and Customs (2013a) Child and Working Tax Credits statistics: finalised annual awards: 2011 to 2012. Personal Tax Credits Statistics. https://www.gov.uk/government/uploads/system/uploads/attachment_data/file/ 260067/cwtc-awards.pdf (accessed August 15, 2015).

HM Revenue and Customs (2013b) Tobacco Factsheet. Tax \& Duty Bulletins. https://www.uktradeinfo.com/Statistics/ Statistical\%20Factsheets/Tobacco_Factsheet_2013.xls (accessed July 1, 2015).

HM Revenue and Customs (2014a) Main Features of National Insurance Contributions. Tax structure and parameters statistics. https://www.gov.uk/government/statistics/main-features-of-national-insurance-contributions (accessed January 21, 2015).

HM Revenue and Customs (2014b) Accounting for VAT when the standard rate of VAT returned to 17.5 percent." VAT rates, thresholds, fuel scale charges and exchange rates. http://www.hmrc.gov.uk/vat/forms-rates/rates/ratechanges.htm (accessed January 22, 2015).

HM Revenue and Customs (2014c) Income Tax Liabilities Statistics 2011-12 to 2014-15. Income Tax Statistics and Distributions. https:/www.gov.uk/government/statistics/income-tax-liabilities-statistics-tax-year-2011-to-2012-to-tax-year-2014-to-2015 (accessed January 22, 2015).

HM Revenue and Customs (2014d) Rates of Income Tax: 1990-91 to 2014-15. Tax Structure and Parameters Statistics. https://www.gov.uk/government/uploads/system/uploads/attachment_data/file/418669/Table-a2.pdf (accessed January 23, 2015).

HM Revenue and Customs (2014e) Income Tax Personal Allowances and Reliefs: 1990-91 to 2014-15. Tax Structure and Parameters Statistics. https://www.gov.uk/government/uploads/system/uploads/attachment_data/file/418665/ Table-a1.pdf (accessed January 23, 2015).

HM Revenue and Customs (2015) Numbers of taxpayers and registered traders. https://www.gov.uk/government/ uploads/system/uploads/attachment_data/file/424585/Apr15_Numbertaxpayerstraders_bulletin_v0.1.pdf (accessed August 15, 2015).

HM Revenue and Customs: Main Tax Expenditures and Structure Reliefs. Tax expenditures, reliefs and ready reckoners statistics. various issues. https://www.gov.uk/government/uploads/system/uploads/attachment_data/file/389539/ 20141231 expenditure reliefs_v0.3.pdf (accessed August 15, 2015).

HM Treasury (2013) Tax and tax credit rates and thresholds for 2014-15. Autumn Statement 2013. https://www.gov.uk government/publications/tax-and-tax-credit-rates-and-thresholds-for-2014-15/tax-and-tax-credit-rates-andthresholds-for-2014-15 (accessed July 7, 2015).

Immervoll H, Kleven HJ, Kreiner CT, Saez E (2007) Welfare Reform in European Countries: A Microsimulation Analysis. Economic J 117:1-44

Institute for Fiscal Studies (2015) Tax Measures Introduced in each Budget and PBR since 1979. Fiscal Facts. http:// www.ifs.org.uk/uploads/publications/ff/budget_measures.xls (accessed July 1, 2015).

Keen M, Mintz J (2004) The Optimal Threshold for a Value-Added Tax. J Public Econ 88(3-4):559-76

KPMG (2013) United Kingdom: VAT essentials. kpmg.com. https://web.archive.org/web/20150618111351/http:// www.kpmg.com/global/en/issuesandinsights/articlespublications/vat-gst-essentials/pages/united-kingdom.aspx (accessed January 22, 2015).

Mendoza EG, Razin A, Tesar LL (1994) Effective Tax Rates in Macroeconomics: Cross-country Estimates of Tax Rates on Factor Incomes and Consumption. J Monet Econ 34(3):297-323

Mulligan CB (2012) The Redistribution Recession. Oxford University Press, New York, redistributionrecession.com 
Mulligan, CB (2013) Recent Marginal Labor Income Tax Changes by Skill and Marital Status. Tax Policy and the Economy: 69-100

Mulligan, CB (2014) Side Effects: The Economic Consequences of the Health Reform. (acasideeffects.com).

Mulligan, CB (2015a) The New Full-time Employment Taxes. Tax Policy and the Economy

Mulligan, CB (2015b) The New Employment and Income Taxes. Journal of Policy Analysis and Management

OECD (2012) Taxing Wages 2011. OECD Publishing, Paris

OECD (2014) Consumption Tax Trends 2014. OECD Publishing

Office for Budget Responsibility (2015) Economic and Fiscal Outlook - March 2015. Controller of Her Majesty's Stationery Office

Office for National Statistics (2012) Families and Households, 2001 to 2011. http:/www.ons.gov.uk/ons/rel/family-demography/ families-and-households/2011/rft-tables_1-to-8.xls (accessed August 15, 2015).

Office for National Statistics (2013) Table P01UK. 2011 Census, Population Estimates. http://www.ons.gov.uk/ons/rel/census/ 2011-census/population-estimates-by-five-year-age-bands-and-household-estimates-for-local-authorities-in-the-unitedkingdom/rft-table-p01uk.xls (accessed August 15, 2015).

Office for National Statistics (2014a) Distribution of Gross Hourly Earnings of Employees. Labour Market Statistics. http:// www.ons.gov.uk/ons/rel/lms/labour-market-statistics/december-2014/table-earn08.xls (accessed January 20, 2015).

Office for National Statistics (2014b) Employment, Unemployment, and Economic Inactivity by Age Group. Labour Market Statistics. http://www.ons.gov.uk/ons/rel//ms/labour-market-statistics/may-2014/table-a05.xls (accessed June 27, 2015).

Onji K (2009) The response of firms to eligibility thresholds: Evidence from the Japanese value-added tax. J Public Econ 93(5-6):766-75

Tax Policy Center (2014) Taxation and the Family: What is the Earned Income Tax Credit? The Tax Policy Briefing Book. http://www.taxpolicycenter.org/briefing-book/key-elements/family/eitc.cfm (accessed July 6, 2015).

Vial A (2012) UK fuel price: how has it changed over time? The Guardian. online edition.

\section{Submit your manuscript to a SpringerOpen ${ }^{\circ}$} journal and benefit from:

- Convenient online submission

- Rigorous peer review

- Immediate publication on acceptance

- Open access: articles freely available online

- High visibility within the field

- Retaining the copyright to your article

Submit your next manuscript at $\boldsymbol{\nabla}$ springeropen.com 